\title{
Assessment of The Effect of Niacin-Hedra helix Extract Combined Treatment on Some Biochemical Parameters in Induced-Asthma Male Mice
}

Mohamed M. Elghazaly ${ }^{1}$, Eman Hashem Radwan ${ }^{1,4 *}$, Ghada Tabl ${ }^{2}$, Nisreen El Gendy ${ }^{1}$ and Kh. H. Radwan ${ }^{3,4}$

1. Damanhour University, Faculty of Science, Zoology Department

2. Tanta University Faculty of Science Zoology Department

3. Agriculture Genetic Engineering Research Institute (AGERI)

4. Member of National Biotechnology Network of Expertize (ASRT)

*Corresponding author ; eman.radwan@sci.dmu.edu.eg, dr_eman radwan@yahoo.com

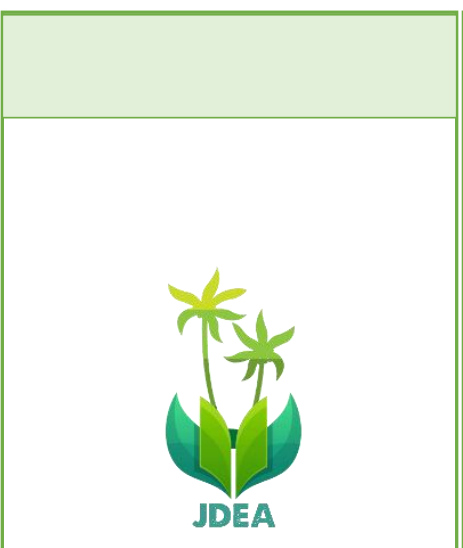

\section{$\underline{\text { Abstract }}$}

The point of the present work was intended to think about the impacts of Niacin, Hedera helix on the asthma. Related parameters after enlistment of asthma for 28 days and in Balb/c mice, notwithstanding research a plausibility of accomplishing a joined advantage of niacin and Hedera helix treatment on cytokines, total protein and the histological examination of lung. The white and differential blood count in BAL (Eosinophil infiltration) is the Asthma marker. The activity level of GSH in the tissue of lung of mice recorded significant increases $(\mathrm{p} \leq$ 0.05 ) and that the level of GSH was significantly decreased in asthma group compared to control group. The group which was treated by a combination increased by $39.9 \%$ compared to the asthma group. The total thiol in lung tissue of mice recorded significant increases in level of T-thiol in all the treated groups compared to asthma group and the group which was treated by niacin, Hedera helix and the group of combination recorded $60.8 \%, 60.6 \%, 68.3 \%$; respectively, while the asthma group recorded a significant decreased. There were significant decreases $(\mathrm{p} \leq$

\section{Article info.}

Received on:28-2-2021

Accepted on: 14-3-2021

Published on: 4-2021

Open Access 0.05 ) in the level of SOD activity in the tissue of mice in niacin, Hedera and niacin -Hedera combination groups as compared to control group, while recording increases of $121.3 \%, 54.7 \%$ and $130.7 \%$ when compared with asthma treated group, the results showed significant decreases in asthma group the data showed the difference between asthma group and niacin group by 0.001 , while with Hedera group 0.602 and combination group 0.001 as compared to asthma group. There was huge increment in TNF- $\alpha$ in asthma group while, in other treated groups there were huge diminished contrasted with asthma niacin, Hedera, niacin-Hedera blend $0.999,0.920$ and 0.812 ; respectively.

Key words: Environment-Niacin-Hedra helix -Biochemical ParametersAsthma- Mice. 


\section{Introduction}

Parts of air contamination incorporate nitrogen dioxide and ozone (D'Amato et al., 2013). Asthma is portrayed by factor and repeating indications, reversible wind stream deterrent, and bronchospasm (NHLBI, 2007). Manifestations incorporate scenes of wheezing, hacking and shortness of breath (Martinez, 2007). Asthma is believed to be brought about by a mix of hereditary and ecological components. Natural components incorporate presentation to air contamination and allergens (WHO, 2013; Horne, 2006). Hedera helix is known as ivy plant or English ivy and is an individual from the Araliaceae family. Preclinical investigations demonstrated that ivy leaf has a spasmolytic, broncho-enlarging and antibacterial impact which is fundamentally owing to the triterpene saponins contained in them (Trute et al., 1997). Ivy leaves extracts display pain relieving, anthelmintic, against mutagenic (Ganji et al., 2009). Niacin is a waterdissolvable nutrient. In human aortic endothelial cells in vitro, niacin fundamentally smothered the bond and gathering of monocytes/macrophages and LDL oxidation (Kuvin et al., 2006). The point of the present work was intended to look at the impacts of Niacin, Hedera helix and their joined treatment on asthma. Related parameters after enlistment of asthma for 28 days and in Balb/c mice.

\section{Asthma}

Advancement of asthma goes through three stages; A mid the enlistment stage, Activation of $\mathrm{T}$ - cells prompts the creation of different cytokines, as tumor necrotic factor-alpha (TNF- $\alpha$ ), interleukins and interferon's (Bradding and Holgate, 1999; Bloemen et al., 2007). Early-stage asthmatic response (EAR) is portrayed by narrowing of aviation route smooth muscle (ASM) cells, vascular spillage (Mainardi et al., 2009). Late stage asthmatic response (LAR) is described by sub-epithelial fibrosis, ASM and epithelial cells hypertrophy (Aulak et al., 2001). ROS can result in lung damage because of direct oxidative harm to epithelial cells and cell shedding (Zheng et al., 2004). ROS have been appeared to be related with the pathogenesis of asthma by inspiring, bronchial hyper reactivity (Nadeem et al., 2005).

\subsection{Eosinophil}

In asthma, eosinophils are thought to assume a basic job in the fiery reaction, as they are available in expanded numbers in broncho-alveolar lavage (BAL) and blood that relates with bronchial hyper responsiveness (Cluzel et al., 1987). Eosinophil activation in vivo outcomes in eosinophil per oxidase (EPO) discharge and oxidative harm to proteins through bromination of tyrosine deposits (Wardlaw et al., 1988; Mitra et al., 2000). Neutrophiland monocyte-derived myeloperoxidase (MPO), which is expanded in smokers, produces 3-chlorotyrosine (Mitra et al., 2000). Alveolar macrophages, and neutrophils from asthmatic patients produce more ROS ( $\mathrm{H} 2 \mathrm{O} 2)$, than do those from typical subjects (Wu et al., 2000). Comhair et al. (2000); Radwan et al., (2017), Radwan et al., (2018); Radwan et al., (2019) have distinguished that debilitated SOD action has been observed to be related with wind current hindrance alongside aviation route hyper responsiveness and renovating. This inactivation of SOD in asthmatics, which has been accounted for in different examinations (Comhair et al., 2000) was because of ROS.

\subsection{In the pulmonary tissue}

There is a distinction between these two ideas since oxygen is available in the alveoli amid lung ischemia. Under this condition, alveolar oxygen keeps up vigorous digestion, deferring hypoxia (Gillissen et al., 1997a). At the point when oxygen is reintroduced into the earth through reperfusion or ventilation, the $\mathrm{O}$ radical is shaped by the impact of xanthine oxidase on hypoxanthine (Gillissen et al., 1997b). The nonattendance of blood stream 
in the lungs may cause lipid peroxidation and oxidative harm (Lapenna et al., 1995). This kind of harm isn't identified with ATP exhaustion and subsequently can't be obstructed by xanthine oxidase inhibitors (Gillissen et al., 1997b). The endothelium is by all accounts one of the significant oxidant sources in non-hypoxic lung ischemia brought about by the enactment of nicotinamide adenine di-nucleotide phosphate (NADPH)- oxidase and of the NF-kB factor, just as by calcium/calmodulin-subordinate nitric oxide synthase (Yasui et al., 2000; IAG, 2002). Oxidants actuate expanded apoptosis of bronchial epithelial cells from asthmatic subjects (Sieben et al., 2009; CHMP, 2009). In vitro introduction of auxiliary and provocative cells of the lungs to oxidants actuates the arrival of master fiery go in between including cytokines, chemokines and attachment atoms associated with incendiary cell enlistment in asthma (Stauss-Grabo and Atiye, 2009).

In vitro oxidative pressure can initiate enactment of (NF-kB) and activator protein 1 (AP-1), two vital controllers of incendiary procedures (Zeil et al., 2014). Dimensions of EPO and additionally MPO are expanded in the instigated sputum, and broncho alveolar lavage (BAL) liquid from patients with stable asthma (Fario et al., 2009). The expanded levels of many direct and backhanded markers of oxidative pressure (counting malondialdehyde, thiobarbituric corrosive receptive items (TBARs), and $\mathrm{H} 2 \mathrm{O} 2$ ) have been found in the plasma, sputum and lung tissues of patients with asthma. Their dimension is frequently identified with the seriousness of the sickness and is conversely identified with the level of strength (Stauss-Grabo and Atiye, 2009). Peroxynitrite inhibitory action is diminished in the sputum of patients with stable asthma and its dimension is emphatically identified with aviation route responsiveness and adversely identified with constrained expiratory volume in 1 second (FEV1) and the level of sputum eosinophilia. Treatment with breathed in glucocorticoids likewise standardizes the decreased bronchial epithelial CuZn-SOD explicit action (Gaillard et al., 2003).

\subsection{NF-kB}

Rhinovirus contamination of respiratory epithelial cells causes intracellular oxidant age which is a significant advance in the initiation of NF$\mathrm{kB}$ and in the accompanying generation of expert incendiary attachment atoms and cytokines. Decreasing specialists restrain both rhinovirus actuated oxidant age and provocative go between creation and discharge (Hedayati et al., 2001). Oxidants incite expanded apoptosis of bronchial epithelial cells from asthmatic subjects (Sieben et al., 2009). In vitro introduction of basic and incendiary cells of the lungs to oxidants instigates the arrival of professional provocative go between including cytokines, chemokines, development factors, arachidonic corrosive metabolites, and attachment atoms engaged with fiery cell enlistment in asthma (Fario et al., 2009). Inside the core, oxidants prompt changes in quality articulation (Radwan et al., 2016; Radwan et al., 2017; Radwan et al., 2018; Radwan et al., 2019). Curiously, in vitro oxidative pressure can actuate enactment of (NF-kB) and activator protein 1 (AP-1), two significant controllers of incendiary procedures (Zeil et al., 2014, Cwientzek et al., 2011).

Increased levels of many direct and indirect markers of oxidative stress have been found in the sputum, BAL liquid, and lung tissues of patients with asthma. Their dimension is frequently identified with the seriousness of the sickness and is conversely identified with the level of stability (Fario et al., 2009). The investigation of breathed out breath and breathed out condensate has as of late permitted direct evaluation of $\mathrm{H} 2 \mathrm{O} 2$ and nitric oxide and estimation of a few aberrant results of oxidation in those examples. The last are impressions of oxidation on various substrates, for example, proteins (nitrotyrosine), lipids (isoprostanes and ethane), and DNA (hydroxyl deoxy guanosine). The outflow 
of nitrotyrosine is expanded likewise in bronchial and bronchiolar epithelial cells, in smooth muscle cells, and in eosinophils of bronchial aviation routes and lung parenchyma of patients with stable asthma (Bolbot et al., 2004; Veit, 2014). Regardless of whether per oxidases essentially reflect granulocytic aggravation or whether they effectively add to tissue harm in asthma stays to be resolved. Taken together, these information show that oxidative pressure is upgraded in asthma, and that such redox awkwardness isn't bound to the lungs. Many controlled examinations propose that there is a lack of cancer prevention agents with few investigations showing an initiation of the pathways shielding lung cells from oxidant intervened harm in the lungs or flow of asthmatic subjects (StaussGrabo and Atiye, 2009).

\subsection{SOD}

In stable conditions, CuZn-SOD action is lower in steroid innocent asthmatics than in typical subjects (Gaillard et al., 2003). The cell antioxidants vitamin $\mathrm{E}$ inhibits $\operatorname{IgE}$ reactions to unfavorably susceptible upgrades in creatures and dietary nutrient $\mathrm{E}$ levels are contrarily identified with the occurrence of asthma (Aylward, 1979).

There are more than thirty known seleno-proteins, numerous with obscure capacities (Chang-Man et al., 2001; Barnes, 2000; Li et al., 2003). Corticosteroids, the most powerful nonexplicit calming operators, produce considerable improvement in target lung elements of patients with asthma (Sahin et al., 2001; Calikoglu et al., 2002). There has been a surge in interest in herbal medicine, possibly because they have fewer side effects than current therapy (Radwan et al., 2019).

\subsection{Hedera helix}

It is known as normal ivy, is a plant having a place with the Araliaceae family. Ivy leaf separate has been utilized to treat provocative bronchial ailments (Message and Johnston, 2002). It is a notable plant as ivy plant or English ivy and is an individual from the Araliaceae family. Preclinical examinations demonstrated that ivy leaf extricates have a spasmolytic, bronchodilating and antibacterial impact (Aldridge et al., 2002). The patients treated with the ivy leaves remove profit by the extra broncho spasmolytic impact (Ganji et al., 2009; Kharitonov and Barnes, 2001). Antioxidants have the capacity to shield the body from harms brought about by free radicals initiated oxidative stress (Richardson and Benjamin, 2002).

\subsection{Niacin}

It is a water-dissolvable nutrient. Numerous examinations showed niacin has the calming properties. In human aortic endothelial cells in vitro, niacin fundamentally stifled the grip and collection of monocytes/macrophages and hindered angiotensin II-actuated responsive oxygen species (ROS) creation and LDL oxidation (Cookson, 1999; Holt et al., 1999). Niacin is the nutrient B3 and has central jobs as a component of decrease/oxidation coenzymes engaged with vitality digestion, amino corrosive digestion, and detoxification responses for medications and different substances. Niacin (B3) is essential to cell digestion, mainly through its job in the coenzymes, nicotine-adenine dinucleotide (NAD) and nicotine-adenine dinucleotide phosphatate (NADP), in oxidation-decrease responses. Niacin is principally processed in the liver to niacinamide (nicotinamide) and different subsidiaries (Villani et al., 2001).

\section{Material and methods:}

All chemical and reagent utilized were of scientific evaluation, ova egg whites, niacin, aluminum hydroxide (Alum) was acquired from sigma-Aldrich concoction co (St. Louis, Mo, USA.). Hedera helix extract was acquired from EGY pharmaceutical (EGY Pharma) as syrup. 


\subsection{Experimental animals:}

Pathogen free 22 days, male $\mathrm{BALB} / \mathrm{c}$ mice (Mus musculus), gauging 25-30 gm, were gotten from test animals house of Alexandria University, Alexandria, Egypt. They were kept in clean cages put in a well-ventilated animal house. There were similarly and haphazardly separated into five gatherings each comprising of seven mice for every confine and kept on basal eating regimen and faucet water not indispensable and kept up at $25 \pm 1{ }^{\circ} \mathrm{C}$ with $12 \mathrm{hrs}$ dark and light cycle.

\subsection{Experimental design:}

\section{2,1. Induction of asthma and treatment:}

After two weeks of acclimation mice, were randomly divided into five equal groups as follow:

Group I, Control group: Mice of this group were orally received $0.5 \mathrm{ml}$ saline as vehicle by gavage, for 28 days. Group II, (OVA- group): Mice were received orally Ovalbumin dissolved into saline as asthmatic group. Group III, (OVA+niacin group): On day 14, asthmatic mice were treated with niacin $(40 \mathrm{mg} / \mathrm{kg}$ dissolved in saline) to 27 days (the last day of challenge). Group IV, (OVA+Hedra helix extract group): On day 14, asthmatic mice were treated daily with Hedera helix extract $(100 \mathrm{mg} / \mathrm{kg})$ to day 27 of experiment (the last day of challenge). Group V, (OVA+niacin and Hedera helix extract group): Asthmatic mice were treated with Hedera helix extract $(100 \mathrm{mg} / \mathrm{kg})$ and niacin $(40 \mathrm{mg} / \mathrm{kg})$.

\subsection{Ovalbumin induced Asthma model in mice:}

The mice were sensitized by means of two intra-peritoneal infusions, on day 0 and day 14 of the test, with with $0.2 \mathrm{ml}$ saline containing $20 \mu \mathrm{g}$ ovalbumin adsorbed in $0.4 \mathrm{mg}$ aluminum hydroxide (Alum.) as adjuvant. On days 25-27, mice were anesthetized with $0.2 \mathrm{ml}$ i.p. of ketamine $(0.44 \mathrm{mg} / \mathrm{ml})$ before accepting an intranasal dose of $100 \mu \mathrm{g}$ ova albumin in a $50 \mu \mathrm{l}$ volume of saline. OVA-tested group got $40 \mathrm{mg} / \mathrm{kg}$ Hedera helix leaf powder extract as Hedera helix syrup. The concentrate was given by intra peritoneal administration at $1 \mathrm{~h}$ before OVA challenge on days 25-27. Mice without OVA exposure (control-Hedera helix) received got a similar portion of Hedera helix received on days 25-27 BALB/c mice were utilized for this investigation as they are high $\operatorname{IgE}$ responders.

\subsection{Measured parameters:}

\subsubsection{Blood sample:}

After 24 hours from the finishing of exploratory period on day 28, 24 hours after last injection, organization, mice were anesthetized with diethyl either and yielded by cervical dislocation. The initial part of blood was taken by the heart puncture utilizing sterile syringe. The blood samples were set in weatherman tubes containing EDTA. For differential count, the other part of the blood was centrifuged at $4000 \mathrm{~g}$ for $10 \mathrm{~min}$ (Hettich zentrifugen, widespread 320R, Germany) and the serum was gathered for the determination of the biochemical parameters at $20^{\circ} \mathrm{C}$. The lung tissue was promptly confined from the mice after their scarification and washed with cold saline arrangement. Pieces from lung tissues were fixed in formaldehyde for the histological examinations. Likewise, one fourth lung tissue was minced and homogenized independently in $5 \mathrm{ml}$ of $5 \%$ trichloroacetic corrosive, containing 0.003 $\mathrm{M}$ disodium salt of ethylene diamine tetra acidic corrosive (TCA/EDTA). The homogenate was centrifuged at $4000 \mathrm{~g}$ for $10 \mathrm{~min}$. at that point the supernatants were put away at $-80{ }^{\circ} \mathrm{C}$ for determination of the required parameters.

\subsection{Biochemical parameters:}

Estimation of total and differential leukocytes count; for total leukocytes count was determined according to Coles (1980). The differential leukocytes count was done according to Coles (1980). Estimation of 
oxidative stress biomarker (MDA) malondialdehyde formation in the tissue was done according to the method of Yoshioka et al. (1979). Estimation of superoxide dismutase (SOD) activity was assayed by the method of Misra and Fridovich (1972). Estimation of reduced glutathione concentration (GSH) was measured by the method of Jollow et al. (1974). Estimation of total thiol content (T. thiol) was carried out by the method of Sedlak and Lindsay (1968). Total protein concentration (TP) in serum and protein contents in brain regions were assayed by the method of Lowry et al. (1951). Quantitative detection of interleukin-6 by ELISA kit was estimated by the method of Ferguson-Smith et al. (1988). Estimation of Tumor necrosis factor alpha by ELISA kit was estimated by the method of Hedayati et al. (2001). Histo-pathological examinations were done according to Bancroft and Steven (1996).

\section{Immuno-histochemistry:}

Immuno-histochemistry utilizes antibodies to recognize tissue segments of intrigue. It very well may be utilized to recognize both cell types and extracellular lattice segments. The two proteins based and fluorescently based resistant recoloring procedures exist. Protein marked examples are seen in a splendid field after a progression of steps. Fluorescent recoloring will in general be more delicate than catalyst based recoloring, which ought to be viewed as while choosing the recoloring strategy. The initial phases in immunohistochemistry are to segment and mount the tissue. This recoloring method is reliant on the fixative utilized, on the grounds that the immune response epitope might be covered amid obsession. Cryo sectioning is generally a superior alternative, however numerous labs use paraffin implanted segments. In the wake of mounting, the example is brooded with a blocking specialist, for example, ox-like serum egg whites (BSA), so as to avert non-explicit official. In the wake of hindering, the example is hatched with an essential counter acting agent, chose to tie to the antigen of enthusiasm on the tissue, and washed. The example is then hatched with an auxiliary neutralizer, which ties to the essential counter acting agent, going about as an enhancer of the visual flag. On the off chance that fluorescence recoloring is utilized, the optional counter acting agent is commonly marked with a fluorescent tag, and the neutralizer restricting can in this way be pictured after this progression. For catalyst based immune-staining, the optional counter acting agent is labeled with biotin, and extra advances must be completed before representation. It is conceivable to name the essential immunizer; notwithstanding, there is commonly insufficient essential counter acting agent bound to the example to be noticeable. Steptavidin connected to horseradish peroxidase is connected to the tissue area. Diaminobenzidine (DAB) is then included, bringing about a darker shaded hasten shaping where the immune response has bound. Catalyst named areas are frequently further counterstained with hematoxylin to improve perception before survey under a light magnifying lens.

\subsection{Strategy for NF-KB:} in strong):

Staining convention (unit segments

1. Deparaffinize and rehydrate tissue area. 2. Wash multiple times in cradle. 3. Whenever required, brood tissue in stomach related catalyst (or fitting pretreatment). 4. Wash multiple times in support. 5. To decrease nonspecific foundation recoloring because of endogenous peroxidase, hatch slide in Hydrogen Peroxide Block for 10-15 minutes. 6. Wash multiple times in buffer.7. Apply Ultra V Block and hatch for 5 minutes at room temperature to square nonspecific foundation recoloring. 8. Wash (Optional). 9. Apply essential immune response and brood as indicated by producer's suggested convention. 10 . Wash multiple times in support. 11. Apply Primary Antibody Enhancer and hatch for 20 minutes at room temperature. 12. Wash multiple times in support. 13. Apply HRP 
Polymer and hatch for 30 minutes at room temperature. 14. Wash multiple times in cushion. 15. Apply prepared to-utilize AEC Single Solution to tissue. Hatch for 10 minutes. Alter brooding time to enhance recoloring in your lab. 16. Wash multiple times in DI water. 17. Counterstain and spread slip utilizing a fluid mounting media. The explicitness and affectability of antigen discovery is reliant on the particular essential immune response utilized.

\subsection{Statistical analysis:}

The outcomes acquired in the present examination were measurably dissected utilizing one way ANOVA. Measurable introduction and examination of the present investigation were communicated as Mean \pm S.E. utilizing segment measurements with NewmanKeuls Multiple Comparison Test as a posttest utilizing the PC insights Prism 3.0 bundle (Graph Pad Software, Inc, San Diego, CA, USA). The base dimension of measurable essentialness was set at $\mathrm{p}<0.05$.

\section{Results:}

3.1. Effects of treatment with niacin or potentially Hedera helix and their mix on oxidative stress biomarkers in asthma mice model: The oxidative stress biomarkers, for example, malondialdehyde (MDA) was estimated to assess the oxidative damage happened by ovaalbumin and treatment impact brought about by niacin as well as Hedera helix extract.

Table (1): Effect of niacin and/or Hedera helix co-treatment on malondialdehyde (MDA) level in lung tissue $(\mathrm{n} \mathrm{mol} / \mathrm{ml})$ of male mice:

\begin{tabular}{|c|c|c|c|c|c|c|c|}
\hline \multirow{2}{*}{$\begin{array}{c}\text { MDA } \\
\text { (nmol/g tissue) }\end{array}$} & \multirow[b]{2}{*}{$\begin{array}{l}\text { Control } \\
(\mathbf{n}=5)\end{array}$} & \multirow[b]{2}{*}{$\begin{array}{l}\text { Asthma } \\
(\mathbf{n}=5)\end{array}$} & \multicolumn{3}{|c|}{ Asthma + } & \multirow[b]{2}{*}{$\mathbf{F}$} & \multirow[b]{2}{*}{$\mathbf{P}$} \\
\hline & & & $\begin{array}{c}\text { Niacine } \\
(n=5)\end{array}$ & $\begin{array}{c}\text { Hedera } \\
(\mathbf{n}=5)\end{array}$ & $\begin{array}{c}\text { Niacine+Hedera } \\
(\mathrm{n}=\mathbf{5})\end{array}$ & & \\
\hline Min. - Max. & $7.29-10.42$ & $13.99-20.80$ & $8.19-10.87$ & $7.29-10.20$ & $7.65-10.30$ & \multirow{4}{*}{$26.295^{*}$} & \multirow{4}{*}{$<0.001^{*}$} \\
\hline Mean \pm SD & $1.16 \pm 8.59$ & $2.67 \pm 16.90$ & $1.08 \pm 9.48$ & $1.14 \pm 8.74$ & $1.06 \pm 9.06$ & & \\
\hline SEM. & 0.52 & 1.19 & 0.48 & 0.51 & 0.47 & & \\
\hline Median & 8.63 & 16.70 & 9.70 & 8.80 & 8.90 & & \\
\hline $\mathrm{p}_{\text {Control }}$ & & \multirow[t]{4}{*}{$<0.001^{*}$} & 0.894 & 1.000 & 0.989 & & \\
\hline $\mathrm{p}_{\text {Asthma }}$ & & & $<0.001^{*}$ & $<0.001^{*}$ & $<0.001^{*}$ & & \\
\hline Significance & & & \multicolumn{3}{|c|}{$\mathrm{p}_{1}=0.941, \mathrm{p}_{2}=0.993, \mathrm{p}_{3}=0.997$} & & \\
\hline$\%$ Ch. from asthma & & & $\downarrow 43.9$ & $\downarrow 48.3$ & $\downarrow 46.4$ & & \\
\hline
\end{tabular}

Data expressed as mean \pm SEM. Number of mice per group $(n)=5$ mice . The significant difference between different groups. using ANOVA, F, p: F and p values for ANOVA test, Sig. was done using Post Hoc Test (Tukey). pcontrol: $p$ value for comparing between control and each other groups. $\mathrm{p}_{\text {Asthma: }} \mathrm{p}$ value for comparing between Asthma and each other groups. $\mathrm{p}_{1}$ : $\mathrm{p}$ value for comparing between Asthma + Niacine with Asthma + Hedera. $\mathrm{p}_{2}$ : $\mathrm{p}$ value for comparing between Asthma + Niacine with Asthma + Niacine + Hedera. $\mathrm{p}_{3}: \mathrm{p}$ value for comparing between Asthma + Hedera with Asthma + Niacine + Hedera. *: Statistically significant at $\mathrm{p} \leq 0.05$.

As regards to MDA activity level in the tissue of mice, the data in table (1) indicated that, there were a significant increase in MDA activity level in asthmatic mice compared to control group $(\mathrm{p}<0.001)$ and that the percentage of MDA were $43.9 \%, 48.3 \%$ and $46.4 \%$ after treated with niacin, Hedera helix extract and their combination; respectively.

\subsection{Effects of treatment with niacin and/ or Hedera helix and their combination on antioxidant}

enzymes activity in asthma mice model:

The antioxidant biomarker such as; superoxide dismutase (SOD), reduced glutathione concentration (GSH) and total thiol (T. thiol) activity levels were measured to assess the antioxidant activity of co-treatment on asthma mice model. Effect of niacin and /or Hedera helix cotreatment on reduced glutathione activity level in the tissues. 
Table (2): Effect of niacin and/or Hedera helix co-treatment on GSH ( $\mathrm{mmol} / \mathrm{g}$ tissue) level in lung tissue of male mice:

\begin{tabular}{|c|c|c|c|c|c|c|c|}
\hline \multirow{2}{*}{$\begin{array}{c}\text { GSH } \\
\text { ( } \mathrm{mmol} / \mathrm{g} \text { tissue) }\end{array}$} & \multirow{2}{*}{$\begin{array}{l}\text { Control } \\
(\mathbf{n}=5)\end{array}$} & \multirow{2}{*}{$\begin{array}{l}\text { Asthma } \\
(\mathbf{n}=5)\end{array}$} & \multicolumn{3}{|c|}{ Asthma + } & \multirow[b]{2}{*}{$\mathrm{F}$} & \multirow[b]{2}{*}{$\mathrm{P}$} \\
\hline & & & $\begin{array}{c}\text { Niacine } \\
(n=5)\end{array}$ & $\begin{array}{c}\text { Hedera } \\
(n=5)\end{array}$ & $\begin{array}{c}\text { Niacine+Hedera } \\
(n=5)\end{array}$ & & \\
\hline Min. - Max. & $50.0-62.0$ & $29.20-45.60$ & $40.61-61.22$ & $41.23-52.0$ & $49.0-55.10$ & \multirow{4}{*}{$6.563^{*}$} & \multirow{4}{*}{$0.002^{*}$} \\
\hline Mean \pm SD & $4.96 \pm 53.26$ & $7.29 \pm 37.25$ & $7.44 \pm 50.37$ & $4.35 \pm 48.35$ & $2.35 \pm 52.10$ & & \\
\hline SEM. & 2.22 & 3.26 & 3.33 & 1.95 & 1.05 & & \\
\hline Median & 51.43 & 39.80 & 50.0 & 49.60 & 52.20 & & \\
\hline $\mathrm{p}_{\text {Control }}$ & & \multirow[t]{4}{*}{$0.002^{*}$} & 0.924 & 0.645 & 0.997 & & \\
\hline $\mathrm{p}_{\text {Asthma }}$ & & & $0.011^{*}$ & $0.038^{*}$ & $0.004^{*}$ & & \\
\hline Sig. bet. Grps & & & \multicolumn{3}{|c|}{$\mathrm{p}_{1}=0.978, \mathrm{p}_{2}=0.988, \mathrm{p}_{3}=0.826$} & & \\
\hline$\%$ Ch. from asthma & & & $\uparrow 35.2$ & $\uparrow 29.8$ & $\uparrow 39.9$ & & \\
\hline
\end{tabular}

F,p: $F$ and $p$ values for ANOVA test, Significance between groups was done using Post Hoc Test

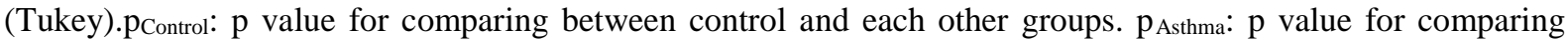
between Asthma and each other groups. $\mathrm{p}_{1}$ : $\mathrm{p}$ value for comparing between Asthma + Niacine with Asthma + Hedera. $\mathrm{p}_{2}$ : $\mathrm{p}$ value for comparing between Asthma + Niacine with Asthma + Niacine + Hedera. $\mathrm{p}_{3}: \mathrm{p}$ value for comparing between Asthma + Hedera with Asthma + Niacine + Hedera. *: Statistically significant at $\mathrm{p} \leq 0.05$.

As illustrated in table (2), the activity level of GSH in the tissue of lung of mice recorded significant increases $(\mathrm{p} \leq 0.05)$ and that the level of GSH was significantly decreased in asthma group compared to control group. Administration of group treated with niacin showed a significant increase by $35.2 \%$ and which was treated with Hedera increase by $29.8 \%$. The group which was treated by a combination increased by $39.9 \%$ compared to the asthma group.

Table (3): Effect of niacin and/or Hedera helix co-treatment on Total thiol (T. thiol) level in lung tissue ( $\mu \mathrm{mol} / \mathrm{g}$ tissue) of mice asthma model:

\begin{tabular}{|c|c|c|c|c|c|c|c|}
\hline \multirow{2}{*}{$\begin{array}{c}\text { T.Thiol } \\
\text { ( } \text { mmol / gr. tissue) }\end{array}$} & \multirow[b]{2}{*}{ Control } & \multirow[b]{2}{*}{ Asthma } & \multicolumn{3}{|c|}{ Asthma + } & \multirow[b]{2}{*}{$\mathbf{F}$} & \multirow[b]{2}{*}{$\mathbf{P}$} \\
\hline & & & Niacine & Hedera & $\begin{array}{c}\text { Niacine + } \\
\text { Hedera }\end{array}$ & & \\
\hline Min. - Max. & $17.04-23.76$ & $10.50-15.36$ & $15.92-23.0$ & $17.0-22.0$ & $17.60-23.54$ & \multirow{4}{*}{$10.378^{*}$} & \multirow{4}{*}{$<0.001^{*}$} \\
\hline Mean \pm SD. & $2.70 \pm 20.94$ & $1.97 \pm 12.19$ & $3.35 \pm 19.60$ & $1.96 \pm 19.58$ & $2.28 \pm 20.52$ & & \\
\hline SEM. & 1.21 & 0.88 & 1.50 & 0.88 & 1.02 & & \\
\hline Median & 21.20 & 11.40 & 20.24 & 19.20 & 20.0 & & \\
\hline $\mathrm{p}_{\text {Control }}$ & & \multirow[t]{4}{*}{$<0.001^{*}$} & 0.912 & 0.907 & 0.999 & & \\
\hline $\mathrm{p}_{\text {Asthma }}$ & & & $0.001^{*}$ & $0.001^{*}$ & $<0.001^{*}$ & & \\
\hline Sig. & & & \multicolumn{3}{|c|}{$\mathrm{p}_{1}=1.000, \mathrm{p}_{2}=0.977, \mathrm{p}_{3}=0.974$} & & \\
\hline$\%$ Ch. from asthma & & & $\uparrow 60.8$ & $\uparrow 60.6$ & $\uparrow 68.3$ & & \\
\hline
\end{tabular}

F,p: $\mathrm{F}$ and $\mathrm{p}$ values for ANOVA test, Significance between groups was done using Post Hoc Test (Tukey). pControl: $\mathrm{p}$ value for comparing between control and each other groups. $\mathrm{p}_{\text {Asthma: }} \mathrm{p}$ value for comparing between Asthma and each other groups. $p_{1}: p$ value for comparing between Asthma + Niacine with Asthma + Hedera. $p_{2}$ : $\mathrm{p}$ value for comparing between Asthma + Niacine with Asthma + Niacine + Hedera. $\mathrm{p}_{3}: \mathrm{p}$ value for comparing between Asthma + Hedera with Asthma + Niacine + Hedera. *: Statistically significant at $\mathrm{p} \leq 0.05$.

As indicated in table (3); T. Thiol in lung tissue of mice recorded significant increases in level of T.Thiol in all The Treated groups compared to asthma group and the group which was treated by niacin,
Hedera helix and the group of combination recorded $60.8 \%, 60.6 \%$, $68.3 \%$; respectively, while the asthma group recorded a significant decreased. 
Table (4): Effect of niacin and/or Hedera helix co-treatment on SOD activity level inhibition level in lung tissue (U/mg protein) of mice asthma model:

\begin{tabular}{|c|c|c|c|c|c|c|c|}
\hline \multirow{2}{*}{$\begin{array}{c}\text { SOD } \\
\text { (U/mg protein) }\end{array}$} & \multirow[b]{2}{*}{ Control } & \multirow[b]{2}{*}{ Asthma } & \multicolumn{3}{|c|}{ Asthma + } & \multirow[b]{2}{*}{$\mathbf{F}$} & \multirow[b]{2}{*}{$\mathbf{P}$} \\
\hline & & & Niacin & Hedera & $\begin{array}{c}\text { Niacin + } \\
\text { Hedera }\end{array}$ & & \\
\hline Min. - Max. & $1.75-1.93$ & $0.67-0.83$ & $1.60-1.74$ & $1.03-1.20$ & $1.59-1.85$ & \multirow{4}{*}{$198.299^{*}$} & \multirow{4}{*}{$<0.001^{*}$} \\
\hline Mean \pm SD & $1.86 \pm 0.07$ & $0.75 \pm 0.06$ & $1.66 \pm 0.06$ & $1.16 \pm 0.07$ & $1.73 \pm 0.10$ & & \\
\hline SEM. & 0.03 & 0.03 & 0.03 & 0.03 & 0.04 & & \\
\hline Median & 1.87 & 0.74 & 1.64 & 1.18 & 1.74 & & \\
\hline$p_{\text {Control }}$ & & \multirow[t]{4}{*}{$<0.001^{*}$} & $0.003^{*}$ & $<0.001^{*}$ & $<0.001^{*}$ & & \\
\hline $\mathrm{p}_{\text {Asthma }}$ & & & $<0.001^{*}$ & $<0.001^{*}$ & $<0.001^{*}$ & & \\
\hline Sig. bet. Grps & & & \multicolumn{3}{|c|}{$\mathrm{p}_{1}<0.001^{*}, \mathrm{p}_{2}=0.602, \mathrm{p}_{3}<0.001^{*}$} & & \\
\hline$\%$ Ch. from asthma & & & $\uparrow 121.3$ & $\uparrow 54.7$ & $\uparrow 130.7$ & & \\
\hline
\end{tabular}

F,p: $\mathrm{F}$ and $\mathrm{p}$ values for ANOVA test, Significance between groups was done using Post Hoc Test (Tukey). $\mathrm{p}_{\text {Control: }} \mathrm{p}$ value for comparing between control and each other groups. $\mathrm{p}_{\text {Asthma: }} \mathrm{p}$ value for comparing between Asthma and each other groups. $p_{1}$ : $p$ value for comparing between Asthma + Niacine with Asthma + Hedera. $p_{2}$ : $\mathrm{p}$ value for comparing between Asthma + Niacine with Asthma + Niacine + Hedera. $\mathrm{p}_{3}: \mathrm{p}$ value for comparing between Asthma + Hedra with Asthma + Niacine + Hedera. *: Statistically significant at $\mathrm{p} \leq 0.05$.

As shown in table (4), the results indicated that, there was significantly decreased $(p \leq 0.05)$ in the level of SOD activity in the tissue of mice in niacin, Hedera and niacin -Hedera combination groups as compared to control group recording $121.3 \%, 54.7 \%$ and $130.7 \%$, the results showed significant decreases in asthma group the data showed the difference between asthma group and niacin group by 0.001 , while with Hedera group 0.602 and combination group 0.001 as compared to asthma group.

\subsection{Total Protein (Tp):}

Table (5): Effect of treatment with niacin and/or Hedera helix on serum total protein (TP) (g/dL) in asthma mice model:

\begin{tabular}{|c|c|c|c|c|c|c|c|}
\hline \multirow[b]{2}{*}{ TP (g/dL) } & \multirow{2}{*}{$\begin{array}{c}\text { Control } \\
(\mathbf{n}=5)\end{array}$} & \multirow{2}{*}{$\begin{array}{l}\text { Asthma } \\
(\mathbf{n}=5)\end{array}$} & \multicolumn{3}{|c|}{ Asthma + } & \multirow[b]{2}{*}{$\mathbf{F}$} & \multirow[b]{2}{*}{$\mathbf{P}$} \\
\hline & & & $\begin{array}{c}\text { Niacine } \\
(n=5)\end{array}$ & $\begin{array}{c}\text { Hedra } \\
(n=5)\end{array}$ & $\begin{array}{c}\text { Niacine + Hedra } \\
(n=5)\end{array}$ & & \\
\hline Min. - Max. & $5.31-6.20$ & $2.87-5.0$ & $4.99-6.20$ & $4.98-6.0$ & $5.03-6.10$ & \multirow{4}{*}{$7.940^{*}$} & \multirow{4}{*}{$0.001^{*}$} \\
\hline Mean \pm SD & $8.83 \pm 0.35$ & $4.01 \pm 0.96$ & $5.49 \pm 0.53$ & $5.32 \pm 0.46$ & $5.79 \pm 0.45$ & & \\
\hline SEM. & 0.16 & 0.43 & 0.24 & 0.20 & 0.20 & & \\
\hline Median & 5.83 & 4.0 & 5.31 & 5.04 & 5.96 & & \\
\hline $\mathrm{p}_{\text {Control }}$ & & $0.001^{*}$ & 0.897 & 0.667 & 1.000 & & \\
\hline $\mathrm{p}_{\text {Asthma }}$ & & & $0.006^{*}$ & $0.017^{*}$ & $0.001^{*}$ & & \\
\hline Sig. bet. Grps & & & \multicolumn{3}{|c|}{$\mathrm{p}_{1}=0.990, \mathrm{p}_{2}=0.928, \mathrm{p}_{3}=0.721$} & & \\
\hline$\%$ Ch. from asthma & & & $\uparrow 36.9$ & $\uparrow 32.7$ & $\uparrow 44.4$ & & \\
\hline
\end{tabular}

F,p: $\mathrm{F}$ and $\mathrm{p}$ values for ANOVA test, Significance between groups was done using Post Hoc Test (Tukey). pontrol: $\mathrm{p}$ value for comparing between control and each other groups. $\mathrm{p}_{\text {Asthma: }} \mathrm{p}$ value for comparing between Asthma and each other groups. $p_{1}$ : $p$ value for comparing between Asthma + Niacine with Asthma + Hedera.p $p_{2}$ : $\mathrm{p}$ value for comparing between Asthma + Niacine with Asthma + Niacine + Hedera. $\mathrm{p}_{3}: \mathrm{p}$ value for comparing between Asthma + Hedera with Asthma + Niacine + Hedera. *: Statistically significant at $\mathrm{p} \leq 0.05$.

The concentration of serum total protein (T.P.) was significantly $(\mathrm{p} \leq 0.05)$ decreased in OVA-treated group compared to control group table (5), the niacin treated group caused significant $(\mathrm{p} \leq 0.05)$ increase in T.P. compared to asthma group $36.9 \%$. The other two groups showed that 32.7 and 44.4 Hedera and co-treatment 
respectively. The treated groups showed increases compared to asthma group while, compared to control group showed significant increase.

\subsection{Tumor Necrosis Factor- $\alpha$ (TNF- $\alpha)$ :}

Table (6): Effect of treatment with niacin and/or Hedera helix on TNF- $\alpha(\mathrm{pg} / \mathrm{mL})$ in serum of asthma mice model:

\begin{tabular}{|c|c|c|c|c|c|c|c|}
\hline \multirow{2}{*}{ TNF- $\alpha(p g / m L)$} & \multirow{2}{*}{ Control } & \multirow{2}{*}{ Asthma } & \multicolumn{3}{|c|}{ Asthma + } & \multirow{2}{*}{$\mathbf{F}$} & \multirow{2}{*}{$\mathbf{p}$} \\
\hline & & & Niacine & Hedra & Niacine + Hedra & & \\
\hline Min. - Max. & $0.79-0.86$ & $1.5-1.63$ & $0.86-1.20$ & $0.88-1.10$ & $0.88-1.0$ & \multirow{4}{*}{$58.468^{*}$} & \multirow{4}{*}{$<0.001^{*}$} \\
\hline Mean \pm SD & $0.83 \pm 0.03$ & $1.57 \pm 0.06$ & $0.98 \pm 0.13$ & $1.0 \pm 0.11$ & $0.94 \pm 0.05$ & & \\
\hline SEM. & 0.01 & 0.03 & 0.06 & 0.05 & 0.02 & & \\
\hline Median & 0.84 & 1.55 & 0.95 & 1.00 & 0.92 & & \\
\hline $\mathrm{p}_{\text {Control }}$ & & $<0.001^{*}$ & 0.067 & $0.040^{*}$ & 0.292 & & \\
\hline $\mathrm{p}_{\text {Asthma }}$ & & & $<0.001^{*}$ & $<0.001^{*}$ & $<0.001^{*}$ & & \\
\hline Sig. bet. Grps & & & \multicolumn{3}{|c|}{$\mathrm{p}_{1}=0.999, \mathrm{p}_{2}=0.920, \mathrm{p}_{3}=0.812$} & & \\
\hline $\begin{array}{c}\% \text { Ch. from } \\
\text { asthma }\end{array}$ & & & $\downarrow 37.6$ & $\downarrow 36.3$ & $\downarrow 40.1$ & & \\
\hline
\end{tabular}

F,p: $\mathrm{F}$ and $\mathrm{p}$ values for ANOVA test, Significance between groups was done using Post Hoc Test (Tukey). pControl: $\mathrm{p}$ value for comparing between control and each other groups. $\mathrm{p}_{\text {Asthma: }} \mathrm{p}$ value for comparing between Asthma and each other groups. $p_{1}: p$ value for comparing between Asthma + Niacine with Asthma + Hedra. $p_{2}: p$ value for comparing between Asthma + Niacine with Asthma + Niacine + Hedra. $\mathrm{p}_{3}: \mathrm{p}$ value for comparing between Asthma + Hedra with Asthma + Niacine + Hedra. *: Statistically significant at $\mathrm{p} \leq 0.05$

As illustrated in table (6), the result showed that, there were significant increase in TNF- $\alpha$ in asthma group while, in other treated groups there were significant decreased compared to asthma group niacin , Hedera, niacin- Hedera combination $0.999,0.920$ and 0.812 ; respectively on other hand administration of niacin alone showed significant $\mathrm{p} \leq 0.05$ decrease of TNF- $\alpha$.

\subsection{Interleukin-6 (IL-6):}

Table (7): Effect of treatment with niacin and/or Hedera helix on IL-6 (pg/g tissue) in serum of lung tissue of mice model:

\begin{tabular}{|c|c|c|c|c|c|c|c|}
\hline \multirow[b]{2}{*}{ IL6 in-Tissue } & \multirow{2}{*}{$\begin{array}{c}\text { Control } \\
(\mathbf{n}=5)\end{array}$} & \multirow[b]{2}{*}{$\begin{array}{c}\text { Asthma } \\
(\mathbf{n}=5)\end{array}$} & \multicolumn{3}{|c|}{ Asthma + } & \multirow[b]{2}{*}{$\mathbf{F}$} & \multirow[b]{2}{*}{$\mathbf{p}$} \\
\hline & & & $\begin{array}{c}\text { Niacine } \\
(n=5)\end{array}$ & $\begin{array}{c}\text { Hedra } \\
(\mathbf{n}=5)\end{array}$ & $\begin{array}{c}\text { Niacine+Hedra } \\
(n=5)\end{array}$ & & \\
\hline Min. - Max. & $107.1-113.4$ & $115.6-189.2$ & $102.9-112.8$ & $108.6-113.4$ & $108.7-112.0$ & \multirow{3}{*}{2.832} & \multirow{3}{*}{0.052} \\
\hline Mean \pm SD & $110.42 \pm 2.34$ & $133.74 \pm 31.14$ & $108.88 \pm 3.72$ & $111.02 \pm 1.88$ & $109.98 \pm 1.29$ & & \\
\hline $\begin{array}{l}\text { SEM. } \\
\text { Median }\end{array}$ & $\begin{array}{c}1.04 \\
110.30\end{array}$ & $\begin{array}{c}13.92 \\
121.50\end{array}$ & $\begin{array}{c}1.67 \\
110.0\end{array}$ & $\begin{array}{c}0.84 \\
111.0\end{array}$ & $\begin{array}{c}0.58 \\
109.6\end{array}$ & & \\
\hline $\mathrm{p}_{\text {Control }}$ & & 0.105 & 1.000 & 1.000 & 1.000 & & \\
\hline $\mathrm{p}_{\text {Asthma }}$ & & & 0.075 & 0.119 & 0.096 & & \\
\hline Sig. bet. Grps & & & \multicolumn{3}{|c|}{$\mathrm{p}_{1}=0.999, \mathrm{p}_{2}=1.000, \mathrm{p}_{3}=1.000$} & & \\
\hline$\%$ Ch. from asthma & & & $\downarrow 18.6$ & $\downarrow 17.0$ & $\downarrow 17.8$ & & \\
\hline
\end{tabular}

F, p: $\mathrm{F}$ and $\mathrm{p}$ values for ANOVA test, Significance between groups was done using Post Hoc Test (Tukey). p control: $p$ value for comparing between control and each other groups. $p_{\text {Asthma: }} p$ value for comparing between Asthma and each other groups. $p_{1}: p$ value for comparing between Asthma + Niacine with Asthma + Hedra. $p_{2}: p$ value for comparing between Asthma + Niacine with Asthma + Niacine + Hedra. $\mathrm{p}_{3}: \mathrm{p}$ value for comparing between Asthma + Hedra with Asthma + Niacine + Hedra. *: Statistically significant at $\mathrm{p} \leq 0.05$.

As illustrated in table (7), the result showed that, there were significant increase in IL-6 in asthma group while, in other treated groups there were significant decreased compared to asthma group 
niacin, Hedera, niacin- Hedera combination $18.6 \%, 17.0 \%$ and $17.8 \%$ respectively. The levels of IL-6 more or less near to control value in treated groups. The level of IL-6 in the treated group when administration of niacin alone showed significant decreased by 0.999 compared to asthma group while, in Hedera group showed slightly decreased compared to niacin group while when compared to asthma group recorded 1.00 , the cotreatment of niacin-Hedera recorded 1.00 as same of Hedera group.

\subsection{Total Leukocytes Count:}

Table (8): Comparison between the different studied groups according to total leukocytes count:

\begin{tabular}{|c|c|c|c|c|c|c|c|}
\hline \multirow[b]{2}{*}{ Total leukocyte } & \multirow[b]{2}{*}{$\begin{array}{c}\text { Control } \\
(n=7)\end{array}$} & \multirow[b]{2}{*}{$\begin{array}{c}\text { Asthma } \\
(\mathbf{n}=5)\end{array}$} & \multicolumn{3}{|c|}{ Asthma + } & \multirow[b]{2}{*}{$\mathbf{F}$} & \multirow[b]{2}{*}{$\mathbf{p}$} \\
\hline & & & $\begin{array}{c}\text { Niacine } \\
(n=5)\end{array}$ & $\begin{array}{c}\text { Hedra } \\
(n=5)\end{array}$ & $\begin{array}{c}\text { Niacine+Hedra } \\
(n=5)\end{array}$ & & \\
\hline Min. - Max. & $0.41-0.47$ & $5.8-6.51$ & $3.1-3.4$ & $4.1-4.5$ & $2.7-3.0$ & \multirow{4}{*}{$676.203^{*}$} & \multirow{4}{*}{$<0.001^{*}$} \\
\hline Mean \pm SD & $0.44 \pm 0.03$ & $6.16 \pm 0.33$ & $3.21 \pm 0.12$ & $4.26 \pm 0.15$ & $2.86 \pm 0.11$ & & \\
\hline SEM. & 0.01 & 0.15 & 0.05 & 0.07 & 0.05 & & \\
\hline Median & 0.43 & 6.10 & 3.21 & 4.20 & 2.90 & & \\
\hline $\mathrm{p}_{\text {Control }}$ & & \multirow[t]{4}{*}{$<0.001^{*}$} & $<0.001^{*}$ & $<0.001^{*}$ & $<0.001^{*}$ & & \\
\hline $\mathrm{p}_{\text {Asthma }}$ & & & $<0.001^{*}$ & $<0.001^{*}$ & $<0.001^{*}$ & & \\
\hline Sig. bet. Grps & & & \multicolumn{3}{|c|}{$\mathrm{p}_{1}<0.001^{*}, \mathrm{p}_{2}=0.045^{*}, \mathrm{p}_{3}<0.001^{*}$} & & \\
\hline$\%$ Ch. from asthma & & & $\downarrow 47.9$ & $\downarrow 30.8$ & $\downarrow 53.6$ & & \\
\hline
\end{tabular}

F,p: $\mathrm{F}$ and $\mathrm{p}$ values for ANOVA test, Significance between groups was done using Post Hoc Test (Tukey). pontrol: $\mathrm{p}$ value for comparing between control and each other groups. $\mathrm{p}_{\text {Asthma: }} \mathrm{p}$ value for comparing between Asthma and each other groups. $p_{1}: p$ value for comparing between Asthma + Niacine with Asthma + Hedra. $p_{2}: p$ value for comparing between Asthma + Niacine with Asthma + Niacine + Hedra. $\mathrm{p}_{3}: \mathrm{p}$ value for comparing between Asthma + Hedra with Asthma + Niacine + Hedra. *: Statistically significant at $\mathrm{p} \leq 0.05$.

\subsection{Lung Weight:}

Table (9): Comparison between the different studied groups according to lung weight:

\begin{tabular}{|c|c|c|c|c|c|c|c|}
\hline \multirow[b]{2}{*}{ Lung weight } & \multirow[b]{2}{*}{$\begin{array}{c}\text { Control } \\
(n=4)\end{array}$} & \multirow[b]{2}{*}{$\begin{array}{c}\text { Asthma } \\
(n=4)\end{array}$} & \multicolumn{3}{|c|}{ Asthma + } & \multirow[b]{2}{*}{$\mathbf{F}$} & \multirow[b]{2}{*}{$\mathbf{p}$} \\
\hline & & & $\begin{array}{c}\text { Niacine } \\
(n=4)\end{array}$ & $\begin{array}{c}\text { Hedra } \\
(n=4)\end{array}$ & $\begin{array}{c}\text { Niacine+Hedra } \\
(n=4)\end{array}$ & & \\
\hline Min. - Max. & $0.11-0.19$ & $0.22-0.33$ & $0.16-0.20$ & $0.17-0.21$ & $0.16-0.24$ & \multirow{4}{*}{$12.066^{*}$} & \multirow{4}{*}{$<0.001^{*}$} \\
\hline Mean \pm SD & $0.15 \pm 0.03$ & $0.28 \pm 0.05$ & $0.18 \pm 0.01$ & $0.19 \pm 0.01$ & $0.20 \pm 0.03$ & & \\
\hline SEM. & 0.01 & 0.02 & 0.01 & 0.01 & 0.01 & & \\
\hline Median & 0.15 & 0.28 & 0.18 & 0.20 & 0.20 & & \\
\hline $\mathrm{p}_{\text {Control }}$ & & \multirow[t]{4}{*}{$<0.001^{*}$} & 0.627 & 0.260 & 0.106 & & \\
\hline $\mathrm{p}_{\text {Asthma }}$ & & & $<0.001^{*}$ & $0.002^{*}$ & $0.006^{*}$ & & \\
\hline Sig. bet. Grps & & & \multicolumn{3}{|c|}{$\mathrm{p}_{1}=0.957, \mathrm{p}_{2}=0.751, \mathrm{p}_{3}=0.985$} & & \\
\hline$\%$ Ch. from asthma & & & $\downarrow 35.7$ & $\downarrow 32.1$ & $\downarrow 28.6$ & & \\
\hline
\end{tabular}

F,p: $\mathrm{F}$ and $\mathrm{p}$ values for ANOVA test, Significance between groups was done using Post Hoc Test (Tukey). $\mathrm{p}_{\text {Control: }} \mathrm{p}$ value for comparing between control and each other groups. $\mathrm{p}_{\text {Asthma }}$ : $\mathrm{p}$ value for comparing between Asthma and each other groups. $\mathrm{p}_{1}: \mathrm{p}$ value for comparing between Asthma + Niacine with Asthma + Hedra. $\mathrm{p}_{2}: \mathrm{p}$ value for comparing between Asthma + Niacine with Asthma + Niacine + Hedra. $\mathrm{p}_{3}$ : $\mathrm{p}$ value for comparing between Asthma + Hedra with Asthma + Niacine + Hedra. *: Statistically significant at $\mathrm{p} \leq 0.05$. 
Table (10): Correlation between different studied parameters in control:

\begin{tabular}{|c|c|c|c|c|c|c|c|c|c|}
\hline & & $\begin{array}{c}\text { GSH } \\
\text { ( } \text { mmol/g } \\
\text { tissue) }\end{array}$ & $\begin{array}{c}\text { T.Thiol } \\
\text { (rmol/gr. } \\
\text { tissue) }\end{array}$ & $\begin{array}{c}\text { SOD } \\
\text { (U/mg } \\
\text { protein) }\end{array}$ & $\mathbf{T P}(\mathrm{g} / \mathrm{dL})$ & $\begin{array}{c}\text { TNF- } \alpha \\
(\mathrm{pg} / \mathrm{mL})\end{array}$ & $\begin{array}{l}\text { IL6 in- } \\
\text { Tissue }\end{array}$ & $\begin{array}{c}\text { Total } \\
\text { leukocyte }\end{array}$ & $\begin{array}{c}\text { Lung } \\
\text { weight }\end{array}$ \\
\hline \multirow{2}{*}{$\begin{array}{l}\text { GSH (mmol/g } \\
\text { tissue) }\end{array}$} & $\mathrm{r}$ & & -0.173 & -0.862 & 00.705 & 00.313 & 00.793 & -0.558 & -0.404 \\
\hline & $\mathrm{p}$ & & 00.781 & 00.060 & 00.184 & 00.608 & 00.110 & 00.328 & 00.499 \\
\hline \multirow{2}{*}{$\begin{array}{c}\text { T.Thiol ( } \mathrm{mmol} / \\
\text { gr. tissue) }\end{array}$} & $\mathrm{r}$ & & & 00.133 & 00.333 & -0.102 & 00.435 & -0.366 & -0.706 \\
\hline & $\mathrm{p}$ & & & 00.831 & 00.584 & 00.871 & 00.465 & 00.544 & 00.183 \\
\hline \multirow{2}{*}{$\begin{array}{c}\text { SOD (U/mg } \\
\text { protein) }\end{array}$} & $\mathrm{r}$ & & & & -0.738 & 00.049 & -0.602 & 00.587 & 00.186 \\
\hline & $\mathrm{p}$ & & & & 00.154 & 00.938 & 00.282 & 00.298 & 00.764 \\
\hline \multirow{2}{*}{$\mathrm{TP}(\mathrm{g} / \mathrm{dL})$} & $\mathrm{r}$ & & & & & -0.296 & 00.807 & -0.343 & -0.416 \\
\hline & $\mathrm{p}$ & & & & & 00.629 & 00.099 & 00.572 & 00.486 \\
\hline \multirow{2}{*}{ TNF- $\alpha(\mathrm{pg} / \mathrm{mL})$} & $\mathrm{r}$ & & & & & & 00.297 & -0.497 & -0.526 \\
\hline & $\mathrm{p}$ & & & & & & 00.627 & 00.394 & 00.362 \\
\hline \multirow{2}{*}{ IL6 in-Tissue } & $\mathrm{r}$ & & & & & & & -0.648 & -0.825 \\
\hline & $\mathrm{p}$ & & & & & & & 00.237 & 00.086 \\
\hline \multirow{2}{*}{ Total leukocyte } & $\mathrm{r}$ & & & & & & & & 00.732 \\
\hline & $\mathrm{p}$ & & & & & & & & 00.160 \\
\hline
\end{tabular}

r: Pearson coefficient

Table (11): Correlation between different studied parameters in asthma:

\begin{tabular}{|c|c|c|c|c|c|c|c|c|c|}
\hline & & $\begin{array}{c}\text { GSH } \\
\text { (rmol/g } \\
\text { tissue) }\end{array}$ & $\begin{array}{c}\text { T.Thiol } \\
\text { ( } \text { mmol/gr. } \\
\text { tissue) }\end{array}$ & $\begin{array}{c}\text { SOD } \\
\text { (U/mg } \\
\text { protein) }\end{array}$ & $\begin{array}{c}\text { TP } \\
(\mathrm{g} / \mathrm{dL})\end{array}$ & $\begin{array}{l}\text { TNF-a } \\
(\mathrm{pg} / \mathbf{m L})\end{array}$ & $\begin{array}{l}\text { IL6 in- } \\
\text { Tissue }\end{array}$ & $\begin{array}{c}\text { Total } \\
\text { leukocyte }\end{array}$ & $\begin{array}{l}\text { Lung } \\
\text { weight }\end{array}$ \\
\hline \multirow{2}{*}{$\begin{array}{l}\mathrm{MDA}(\mathrm{nmol} / \mathrm{g} \\
\text { tissue) }\end{array}$} & $\mathrm{R}$ & 00.582 & 00.069 & -0.814 & -0.473 & 00.694 & 00.142 & -0.271 & -0.143 \\
\hline & $\mathrm{P}$ & 0.303 & 0.912 & 0.094 & 0.421 & 0.194 & 0.819 & 0.659 & 0.819 \\
\hline \multirow{2}{*}{$\begin{array}{c}\mathrm{GSH}(\mu \mathrm{mol} / \mathrm{g} \\
\text { tissue })\end{array}$} & $\mathrm{R}$ & & 0.553 & -0.373 & 0.092 & -0.067 & 0.299 & 0.342 & 0.712 \\
\hline & $\mathrm{P}$ & & 0.334 & 0.536 & 0.882 & 0.915 & 0.625 & 0.573 & 0.178 \\
\hline \multirow{2}{*}{$\begin{array}{l}\text { T.Thiol ( mmol / } \\
\text { gr. tissue) }\end{array}$} & $\mathrm{R}$ & & & -0.416 & 0.716 & -0.614 & 0.913* & 0.789 & 0.726 \\
\hline & $\mathrm{P}$ & & & 0.487 & 0.174 & 0.270 & 0.030 & 0.113 & 0.165 \\
\hline \multirow{2}{*}{$\begin{array}{l}\text { SOD }(\mathrm{U} / \mathrm{mg} \\
\text { protein) }\end{array}$} & $\mathrm{R}$ & & & & 0.084 & -0.426 & -0.619 & -0.031 & 0.150 \\
\hline & $\mathrm{P}$ & & & & 0.893 & 0.475 & 0.265 & 0.961 & 0.810 \\
\hline \multirow{2}{*}{$\mathrm{TP}(\mathrm{g} / \mathrm{dL})$} & $\mathrm{R}$ & & & & & -0.733 & 0.594 & $0.964 *$ & 0.604 \\
\hline & $\mathrm{P}$ & & & & & 0.159 & 0.291 & 0.008 & 0.280 \\
\hline \multirow{2}{*}{ TNF- $\alpha(p g / m L)$} & $\mathrm{R}$ & & & & & & -0.433 & -0.657 & -0.723 \\
\hline & $\mathrm{P}$ & & & & & & 0.467 & 0.228 & 0.167 \\
\hline \multirow{2}{*}{ IL6 in-Tissue } & $\mathrm{R}$ & & & & & & & 0.611 & 0.386 \\
\hline & $\mathrm{P}$ & & & & & & & 0.274 & 0.521 \\
\hline \multirow{2}{*}{ Total leukocyte } & $\mathrm{R}$ & & & & & & & & 0.726 \\
\hline & $\mathrm{P}$ & & & & & & & & 00.165 \\
\hline
\end{tabular}

r: Pearson coefficient. 
Table (12): Correlation between different studied parameters in Asthma + Niacine group:

\begin{tabular}{|c|c|c|c|c|c|c|c|c|c|}
\hline & & $\begin{array}{c}\text { GSH } \\
\text { ( } \mathrm{mmol} / \mathrm{g} \\
\text { tissue) }\end{array}$ & $\begin{array}{c}\text { T.Thiol } \\
\text { (rmol/gr. } \\
\text { tissue) }\end{array}$ & $\begin{array}{c}\text { SOD } \\
\text { (U/mg } \\
\text { protein) }\end{array}$ & $\mathbf{T P}(\mathrm{g} / \mathrm{dL})$ & $\begin{array}{l}\text { TNF- } \alpha \\
(\mathrm{pg} / \mathrm{mL})\end{array}$ & $\begin{array}{l}\text { IL6 in- } \\
\text { Tissue }\end{array}$ & $\begin{array}{c}\text { Total } \\
\text { leukocyte }\end{array}$ & $\begin{array}{c}\text { Lung } \\
\text { weight }\end{array}$ \\
\hline \multirow{2}{*}{$\begin{array}{l}\mathrm{MDA}(\mathrm{nmol} / \mathrm{g} \\
\text { tissue })\end{array}$} & $\mathrm{r}$ & $-0.945 *$ & 00.742 & -0.146 & 00.255 & -0.171 & 00.114 & 000.344 & 0.310 \\
\hline & $\mathrm{p}$ & 0.015 & 0.151 & 0.815 & 0.679 & 0.783 & 0.855 & 0.571 & 0.611 \\
\hline \multirow{2}{*}{$\begin{array}{l}\mathrm{GSH}(\mu \mathrm{mol} / \mathrm{g} \\
\text { tissue })\end{array}$} & $\mathrm{r}$ & & -0.601 & -0.102 & -0.181 & -0.147 & -0.123 & -0.189 & -0.403 \\
\hline & $\mathrm{p}$ & & 0.284 & 0.870 & 0.771 & 0.814 & 0.843 & 0.761 & 0.501 \\
\hline \multirow{2}{*}{$\begin{array}{c}\text { T.Thiol ( mmol } \\
\text { / gr. tissue) }\end{array}$} & $\mathrm{r}$ & & & -0.276 & 0.811 & -0.512 & -0.227 & 0.333 & -0.403 \\
\hline & $\mathrm{p}$ & & & 0.653 & 0.096 & 0.378 & 0.713 & 0.584 & 0.501 \\
\hline \multirow{2}{*}{$\mathrm{TP}(\mathrm{g} / \mathrm{dL})$} & $\mathrm{r}$ & & & & & -0.374 & -0.427 & 0.059 & -0.827 \\
\hline & $\mathrm{p}$ & & & & & 0.535 & 0.473 & 0.925 & 0.084 \\
\hline \multirow{2}{*}{ IL6 in-Tissue } & $\mathrm{r}$ & & & & & & & -0.656 & 0.474 \\
\hline & $\mathrm{p}$ & & & & & & & 0.229 & 0.420 \\
\hline
\end{tabular}

r: Pearson coefficient.

Table (13): Correlation between different studied parameters in Asthma + Hedra:

\begin{tabular}{|c|c|c|c|c|c|c|c|c|c|}
\hline & & $\begin{array}{c}\text { GSH } \\
\text { ( } \mathrm{mmol} / \mathrm{g} \\
\text { tissue) }\end{array}$ & $\begin{array}{c}\text { T.Thiol } \\
\text { (rmol/gr. } \\
\text { tissue) }\end{array}$ & $\begin{array}{c}\text { SOD } \\
\text { (U/mg } \\
\text { protein) }\end{array}$ & $\begin{array}{c}\text { TP } \\
(\mathrm{g} / \mathrm{dL})\end{array}$ & $\begin{array}{c}\text { TNF-a } \\
(\mathrm{pg} / \mathrm{mL})\end{array}$ & $\begin{array}{l}\text { IL6 in- } \\
\text { Tissue }\end{array}$ & $\begin{array}{c}\text { Total } \\
\text { leukocyte }\end{array}$ & $\begin{array}{c}\text { Lung } \\
\text { weight }\end{array}$ \\
\hline \multirow{2}{*}{$\begin{array}{l}\text { MDA }(\mathrm{nmol} / \mathrm{g} \\
\text { tissue })\end{array}$} & $\mathrm{r}$ & -0.402 & -0.614 & 00.427 & 00.293 & 00.927 & -0.114 & -0.031 & -0.353 \\
\hline & $\mathrm{p}$ & 0.503 & 0.271 & 0.474 & 0.633 & 0.024 & 0.856 & 0.961 & 0.561 \\
\hline \multirow{2}{*}{$\begin{array}{c}\mathrm{GSH}(\mu \mathrm{mol} / \mathrm{g} \\
\text { tissue })\end{array}$} & $\mathrm{r}$ & & -0.035 & -0.558 & -0.362 & -0.384 & 0.242 & 0.313 & $0.978^{*}$ \\
\hline & $\mathrm{p}$ & & 0.955 & 0.328 & 0.550 & 0.523 & 0.695 & 0.608 & 0.004 \\
\hline \multirow{2}{*}{$\begin{array}{l}\text { T.Thiol ( } \text { mmol } \\
\text { / gr. tissue) }\end{array}$} & $\mathrm{r}$ & & & -0.622 & 0.001 & -0.725 & -0.631 & 0.199 & 0.080 \\
\hline & $\mathrm{p}$ & & & 0.263 & 0.999 & 0.166 & 0.254 & 0.748 & 0.898 \\
\hline \multirow{2}{*}{$\begin{array}{l}\mathrm{SOD}(\mathrm{U} / \mathrm{mg} \\
\text { protein })\end{array}$} & $\mathrm{r}$ & & & & 0.538 & 0.680 & 0.631 & -0.041 & -0.656 \\
\hline & $\mathrm{p}$ & & & & 0.350 & 0.206 & 0.253 & 0.947 & 0.229 \\
\hline \multirow{2}{*}{$\mathrm{TP}(\mathrm{g} / \mathrm{dL})$} & $\mathrm{r}$ & & & & & 0.522 & 0.175 & 0.738 & -0.289 \\
\hline & $\mathrm{p}$ & & & & & 0.367 & 0.778 & 0.155 & 0.638 \\
\hline
\end{tabular}

r: Pearson coefficient. *. 
Table (14): Correlation between different studied parameters in Asthma + Niacine + Hedra:

\begin{tabular}{|c|c|c|c|c|c|c|c|c|c|}
\hline & & $\begin{array}{c}\text { GSH } \\
\text { (mmol/g } \\
\text { tissue) }\end{array}$ & $\begin{array}{c}\text { T.Thiol } \\
\text { (rmol/gr. } \\
\text { tissue) }\end{array}$ & $\begin{array}{c}\text { SOD } \\
\text { (U/mg } \\
\text { protein) }\end{array}$ & $\begin{array}{c}\text { TP } \\
(\mathrm{g} / \mathrm{dL})\end{array}$ & $\begin{array}{c}\text { TNF- } \alpha \\
(\mathrm{pg} / \mathbf{m L} \mathbf{L})\end{array}$ & $\begin{array}{l}\text { IL6 in- } \\
\text { Tissue }\end{array}$ & $\begin{array}{c}\text { Total } \\
\text { leukocyte }\end{array}$ & $\begin{array}{c}\text { Lung } \\
\text { weight }\end{array}$ \\
\hline \multirow[b]{2}{*}{$\begin{array}{l}\text { MDA (nmol/g } \\
\text { tissue) }\end{array}$} & $\mathrm{r}$ & 00.147 & 00.498 & 00.296 & 00.816 & 00.259 & 00.190 & -0.788 & -0.282 \\
\hline & $\mathrm{p}$ & 0.813 & 0.393 & 0.628 & 0.092 & 0.675 & 0.759 & 0.113 & 0.646 \\
\hline \multirow{2}{*}{$\begin{array}{c}\mathrm{GSH}(\mu \mathrm{mol} / \mathrm{g} \\
\text { tissue })\end{array}$} & $\mathrm{r}$ & & 0.628 & 0.290 & 0.252 & -0.124 & -0.563 & -0.411 & 0.013 \\
\hline & $\mathrm{p}$ & & 0.256 & 0.636 & 0.682 & 0.842 & 0.323 & 0.491 & 0.983 \\
\hline \multirow{2}{*}{$\begin{array}{c}\text { T.Thiol ( } \mathrm{mmol} / \\
\text { gr. tissue) }\end{array}$} & $\mathrm{r}$ & & & $0.896 *$ & 0.841 & 0.347 & -0.238 & -0.223 & 0.394 \\
\hline & $\mathrm{p}$ & & & 0.039 & 0.074 & 0.567 & 0.700 & 0.718 & 0.511 \\
\hline \multirow{2}{*}{$\begin{array}{l}\mathrm{SOD}(\mathrm{U} / \mathrm{mg} \\
\text { protein) }\end{array}$} & $\mathrm{r}$ & & & & 0.782 & 0.434 & -0.057 & 0.169 & 0.656 \\
\hline & $\mathrm{p}$ & & & & 0.118 & 0.465 & 0.927 & 0.786 & 0.229 \\
\hline \multirow{2}{*}{ Total leukocyte } & $\mathrm{r}$ & & & & & & & & 0.693 \\
\hline & $\mathrm{p}$ & & & & & & & & 00.194 \\
\hline
\end{tabular}

r: Pearson coefficient. *

\section{Histo-pathological analysis:}

Animals were sacrificed by an overdose of ketamine $(500 \mathrm{mg} / \mathrm{kg}$, intraperitoneally) 24 hours after the last inhalational exposure and histopathological specimens were collected. Tissue specimens were taken from the mid zone of the left lung of mice. Histo-pathological samples were fixed in $10 \%$ formalin for light microscopic evaluation. After fixation, slice from the mid zone of the left lung was embedded in paraffin. Serial sections cut at $5 \mu \mathrm{m}$ were stained with Haematoxylin and Eosin (for routine Histo-pathological examination), with Toluidine Blue (for enumeration of

Fig. A

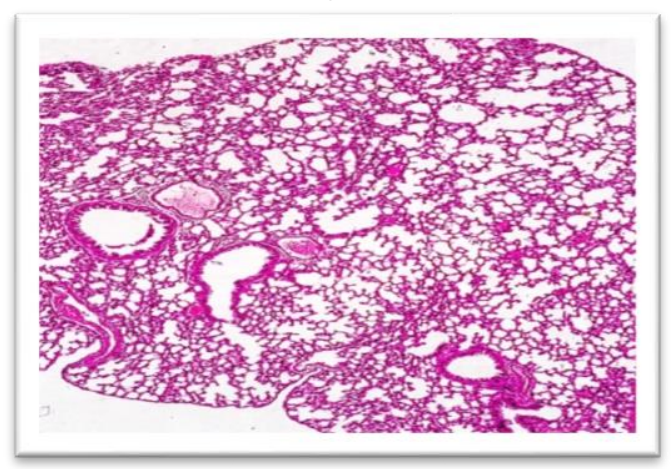

mast cells) and with Periodic Acid Shiff (PAS) (for enumeration of goblet cells).

In asthma group, light microscopic findings revealed irregular respiratory epithelium; some of the cell nuclei were necrotic and degenerative. Increased thickness of epithelium and high numbers of goblet cells were remarkable. Sub-epithelial smooth muscle was markedly thickened. Hedera helix group: In light microscopy, degeneration and abnormality in a portion of the epithelial cells were recognized. Cotreatment group: In light microscopy, degeneration and abnormality in a portion of the epithelial cells were distinguished. H\&E stain, X; 400 .

Fig. B

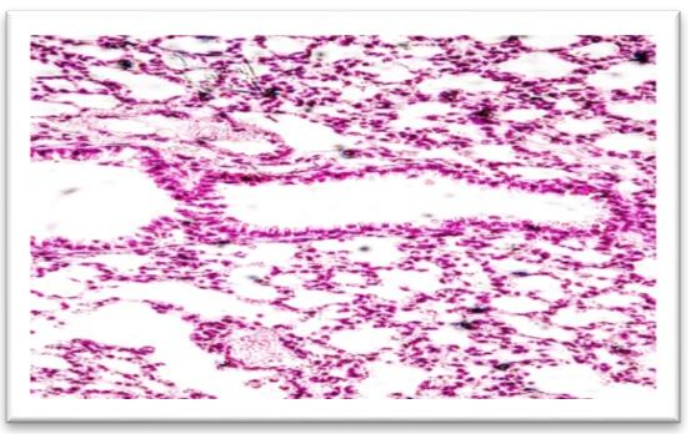

Fig.(1). Light micrographs of lung section of control mice (A) and (B) which received saline only, showing normal nuclei \& blood vessel. H\&E stain, X 400. 
Fig. A

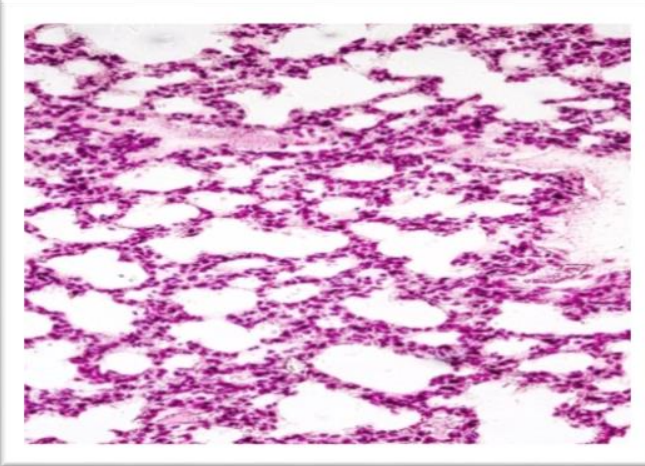

Fig.B

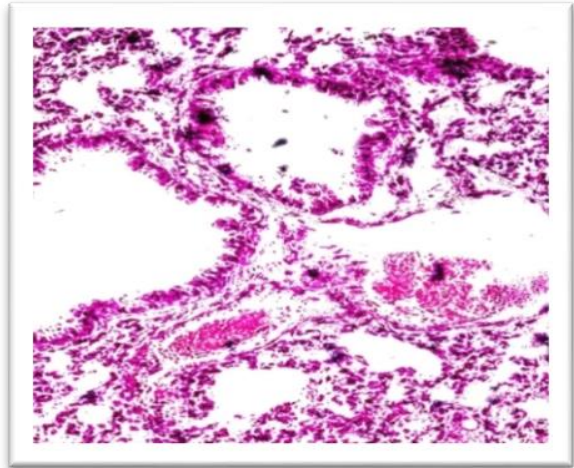

Fig.(2). Light micrographs of lung section of Athma group (A,B)

Fig. A

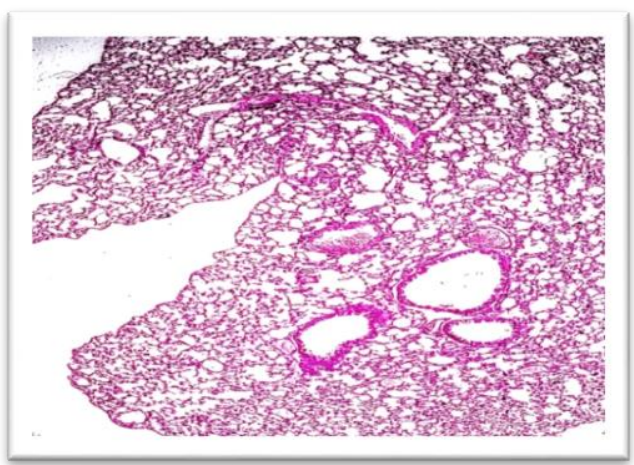

Fig. B

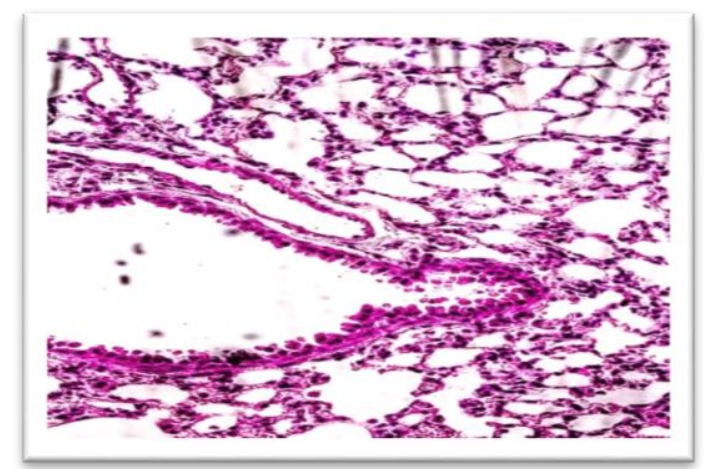

Fig. (3). Light micrographs of lung section of Naiacin group (A,B)

Fig. A

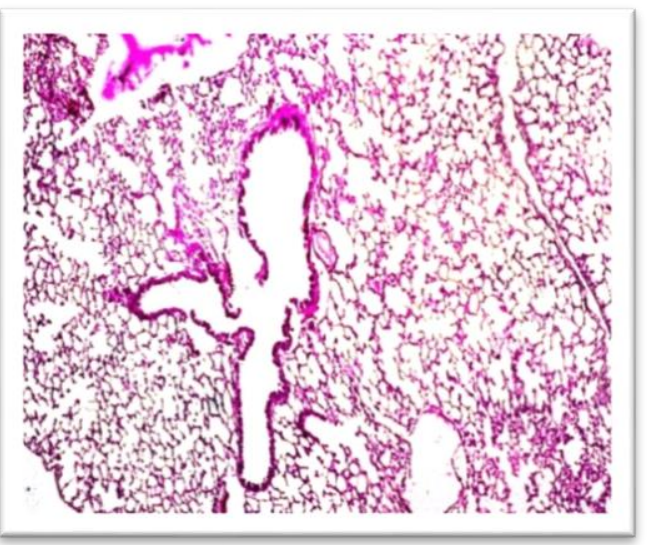

Fig. B

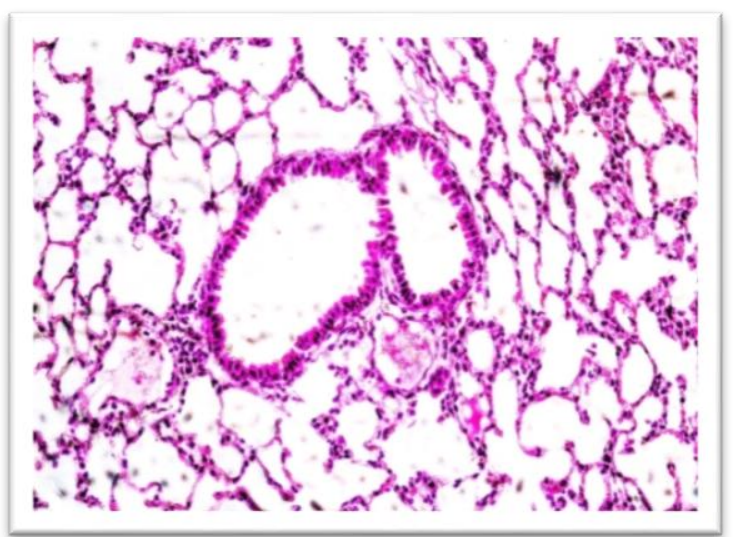

Fig.(4). Light micrographs of lung section of Hedera group (A,B) 
Fig. A

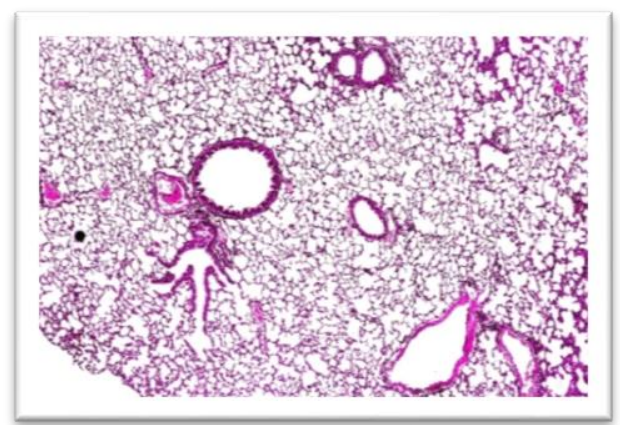

Fig. B

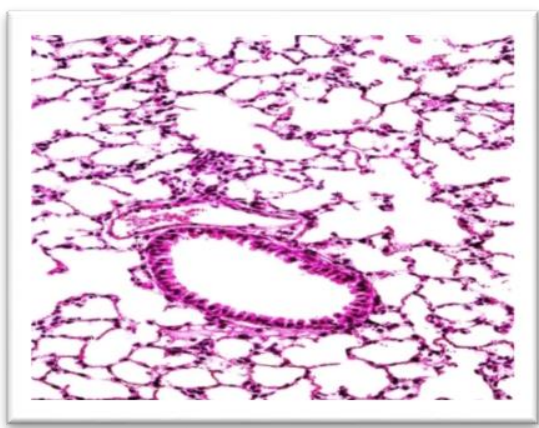

Fig.(5). Light micrographs of lung section of Co-treatment group (A,B)

\section{Figures of Immuno-histochemistry}

Fig.A

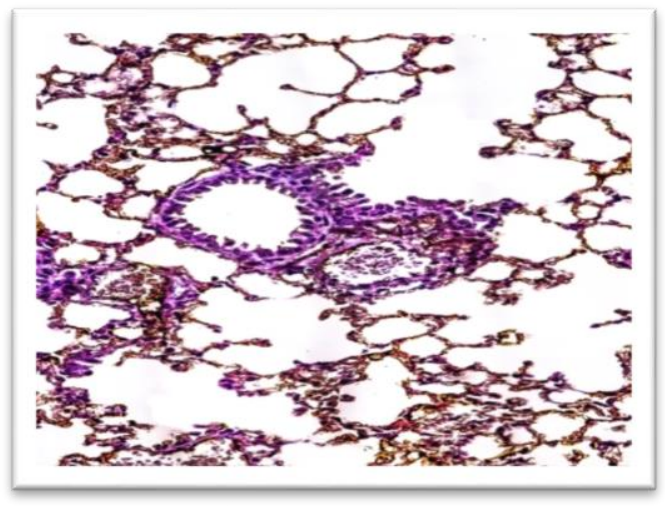

$\underline{\text { Fig. B }}$

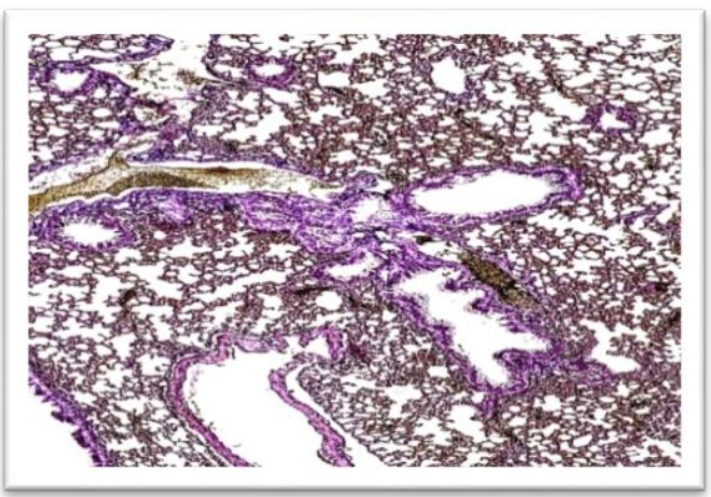

Fig.(6). Light micrographs of lung sections in the control group showing showing normal size and structure of cells

Asthma

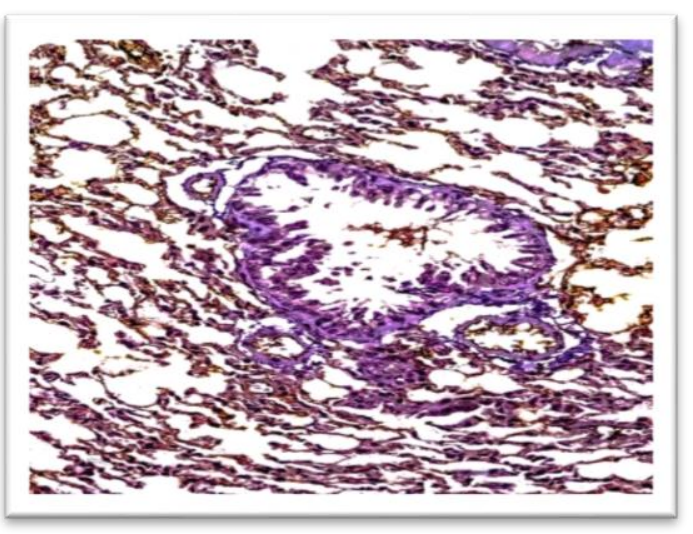

Fig.(7). Light micrographs of lung sections in Asthma group.
Niacin

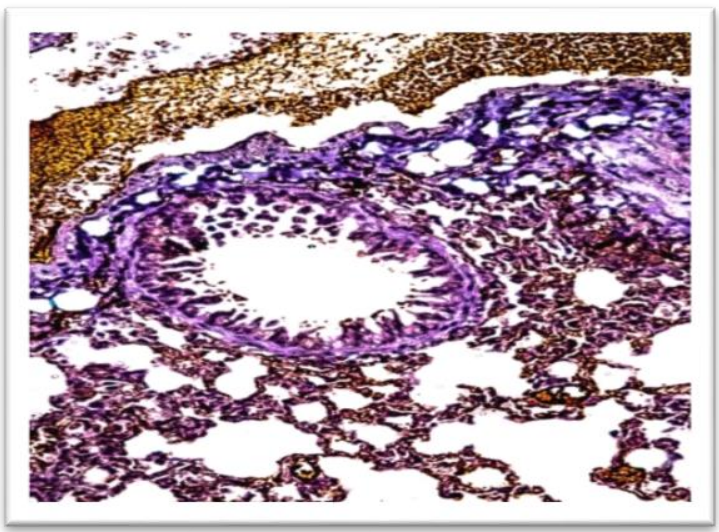

Fig.(8). Light micrographs of lung sections in Niacin group 
$\underline{\text { Fig. A }}$

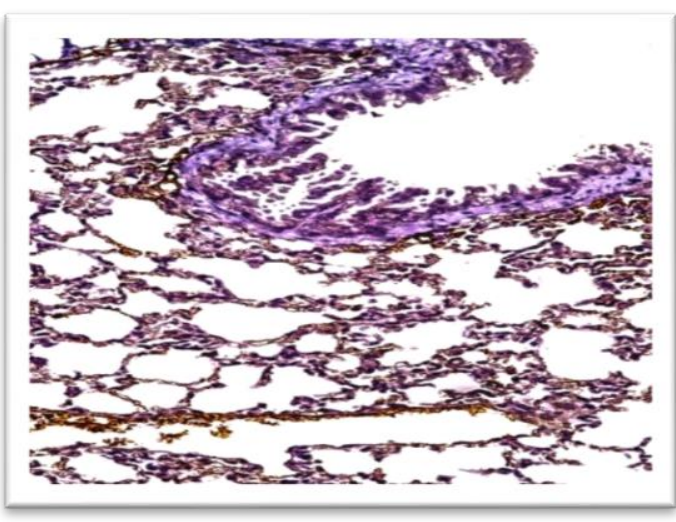

Fig. B

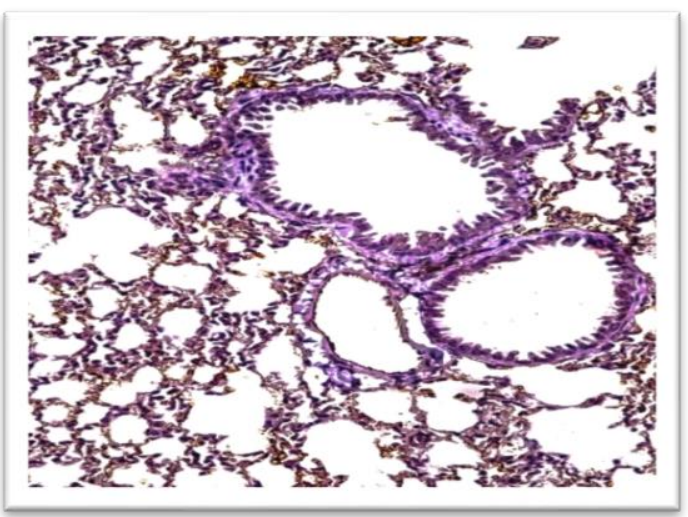

Fig. (9). Light micrographs of lung sections in Hedera helix group(A,B)

Fig. A

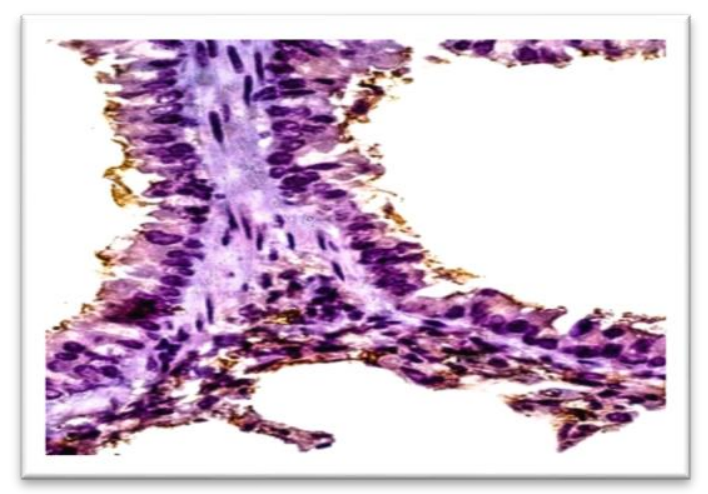

Fig. B

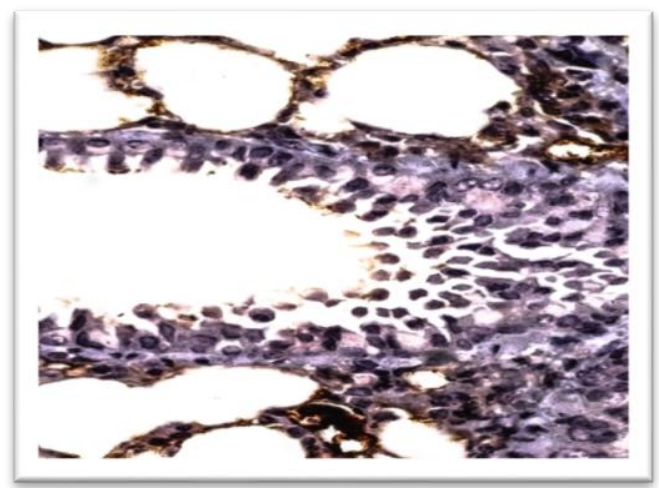

Fig.(10). Light micrographs of lung sections in Co-treatment group $(A, B)$

\section{Discussion}

Asthma is one of the few chronic diseases in the developed world that is expanding in predominance regardless of better comprehension of its pathogenesis and improved medications (Davies et al., 1997). It is a standout amongst the most well-known clutters experienced in clinical prescription in the two kids and grown-ups (Holt et al., 1999). Pathophysiology of asthma is ineffectively comprehended. Numerous logical reports propose that, it includes the initiation of numerous provocative cells like pole cells, macrophages/monocytes, eosinophils, basophils, neutrophils and platelets. It is now increasingly recognized that structural cells may also be important sources of mediators in asthma. Aviation route epithelial cells, smooth muscle cells, endothelial cells and fibroblasts are for the most part fit for integrating and discharging provocative middle people (Barnes et al., 1999). Professional provocative cytokines, for example, TNF- $\alpha$, IL- 6 . They might be significant in sickness seriousness and protection from calming treatment in asthma (Hirala et al., 1998) .

TNF- $\alpha$ being a cytokine is available liberally in asthmatic aviation routes. There is proof that $\operatorname{IgE}$ activating in sharpened lungs prompts expanded articulation in epithelial cells in both rodent and human (Ohkawara et al., 1992). TNF $\alpha$ is available in the BAL liquid of asthmatic patients (Albuquerque et al., 1998). It is accounted for that TNFa is likewise discharged from alveolar macrophages of asthmatic patients after allergen challenge (Gosset et al., 1992). The two monocytes and alveolar 
macrophages show expanded quality articulation of $\mathrm{TNF} \alpha$ after $\operatorname{IgE}$ activating in vitro that is upgraded by INF- $\gamma$ (Yates et al., 1993). Characteristic and elective medicines for asthma incorporate breathing activities, needle therapy, knead treatment, natural prescriptions, and dietary enhancements. Certain blends of Chinese herbs have additionally appeared, however these are not institutionalized and are in this manner not generally accessible. A portion of these elective medicines may in truth be useful, however until there are concentrates to demonstrate an advantage, specialists are hesitant to endorse them and insurance agencies are hesitant to pay for them. Subsequently, numerous patients that they are free to attempt elective medicines alongside standard treatments, yet specialists can't suggest explicit medications. Advancement of more secure and viable enemy of asthmatic medications with extraordinary systems of activity is a significant territory of research (Ribeiro Filho et al., 2013).

The results of the present study showed that both Niacin and ivy leaf extract, effectively suppressed allergic inflammation in a mouse model of asthma. In the present study it was found that these effects of two tested treatments were related to decreased activity of NF-kB. NF- $\kappa B$ is found in practically all animal cell types and is involved with cell reactions to stimuli, for example, stress, cytokines, free radicals, substantial metals, and bacterial or viral antigens NF- $\mathrm{BB}$ assumes a key job in controlling the resistant reaction to disease. Inaccurate guideline of $\mathrm{NF}-\kappa \mathrm{B}$ has been connected to malignant growth and immune system ailments (Gilmore, 2006). In the present examination, niacin diminished lung aggravation and improved cell reinforcement framework brokenness actuated by ova-in mice through down directing the NF- $\kappa \mathrm{B}$ pathway. The present discoveries are in concurrence with Kwon et al. (2011) who announced that Niacin weakens lung aggravation and improves survival amid sepsis by down directing the factor-kappa-B pathway. Niacin, is entrenched for the treatment of dyslipidemia, as it has an intense impact in bringing down plasma LDL-cholesterol and raising HDLcholesterol. Various clinical examinations have exhibited a critical decrease in heart occasions and in cardiovascular ailment related mortality with Niacin treatment (Brown and Zhao, 2008) .

Previous studies in vitro have uncovered that Niacin has properties that are free of its consequences for lipid guideline (Wu et al., 2012). GPR109AGprotein-coupled receptor that quandary and be actuated by Niacin. The calming action of Niacin was recently recorded in a few in vivo and in vitro investigations in which Niacin was appeared to diminish TNF- $\alpha$ expression and production by means of down-controlling factor (NF)- $\kappa B$ initiation signaling pathway. The inhibitory impact of Niacin on TNF- $\alpha$ creation was observed to be interceded by GPR109A (Si et al., 2014). In present study, administration of Niacin resulted in the attenuation of NF-kB activation, decrease in IL-6 level, these discoveries affirm the calming properties of Niacin as appeared by Ganji et al. (2009) in vascular tissue. Hedera helix is normally known as ivy or English ivy, and an individual from the Araliaceae family. It is known to cause contact dermatitis (Ozdemir et al., 2003).

The present examination demonstrated that the dimensions of cytokines were fundamentally expanded by OVA injection. After treatment, ivy extricate diminished TNF- $\alpha$ and IL-6. Co-adminestration with Niacin dose contrasted and ivy treatment alone. Results demonstrated more restraint in these cytokines, and may be in charge of the synergistic increment in calming movement by Niacin. The present outcomes are in concurrence with Gepdiremen et al. (2005) detailed that few noteworthy constituents of ivy extricate purportedly applying mitigating impacts, and are reliant on restraining the development of certain provocative middle people. The expansion in ROS amid an asthma fuel may overpower endogenous cancer prevention agent guards. Glutathione $(\mathrm{GSH})$ is a key cancer prevention agent in the coating liquid of the respiratory tract. 
Improving intracellular GSH can likewise diminish the arrival of cytokines from lung cells by diminishing NF- $\mathrm{BB}$ initiation (Antonicelli et al., 2002). GSH has as of late been accounted for to IL-13 actuated asthma in mice (Lowry et al., 2008). Asthmatic subjects have higher plasma centralizations of isoprotanes; improved generation of ROS in blood monocytes, neutrophils, and eosinophils (Wood et al., 2000).

Numerous investigations have exhibited that Niacin has mitigating impacts in various tissues including kidney (Cho et al., 2009), lung (Kwon et al., 2011) and vascular endothelial cells (Wu et al., 2012). Niacin administration has been appeared to lessen TNF-an, and IL-6 articulation and NF-kB initiation in kidney and lung of rat models (Kwon et al., 2011). Niacin treatment smothers the NF-kB signaling pathway, bringing about diminished emission of the genius fiery cytokines and chemokine TNF-alfa, IL-6 in secluded human monocytes and retinal color epithelial cells (Gambhir et al., 2012). Niacin restrains monocyte chemo taxis (Digby et al., 2010). A large number of these mitigating properties of Niacin have been connected to actuation of the Niacin receptor (Gambhir et al., 2012). The past clarifications are as per the present outcomes which exhibited that Niacin had concealment impact on provocative arbiters initiated by OVA. The present outcomes demonstrated that niacin successfully stifled the movement of NF$\mathrm{kB}$, a redox-delicate translation factor, in the lung tissues through decreased oxidative pressure. NF-kB action is expanded in asthmatic aviation routes (Blesa et al., 2003) and numerous boosts engaged with unfavorably susceptible aggravation have been appeared to enact NF-kB. Numerous provocative proteins communicated in asthmatic aviation routes are directed by NF-kB, including the cytokines IL-6, and TNF-alfa; which are all firmly engaged with the pathogenesis of asthma. Along these lines the improvement of an oxidant-cancer prevention agent unevenness in the lungs of asthmatic patients might be the upgrade that initiates redox-touchy translation factors, for example, NF-kB. A small molecular inhibitor of redox-controlled NF-kB interpretation altogether blocked unfavorably susceptible aviation route aggravation in a mouse model of asthma, recommending that redox-touchy translation variables could be a valuable remedial focus in asthma (Henderson et al., 2002). In the present examination diminished NF-kB movement was joined by a decrease in the dimensions of significant incendiary go between of unfavorably susceptible asthma, for example, IL-6 and TNF-These discoveries are in concurrence with past outcomes from a creature asthma model demonstrating that a reactant cancer prevention agent and $\mathrm{N}$-acetyl cysteine, which act as a free radical scavenger and a precursor of reduced glutathione, could suppress NF-kB, DNA-restricting action, lessen articulation of bond atoms and mucin explicit mRNA in aviation routes, and hinder generation of cytokines, for example, IL-4, IL-5 (Blesa et al., 2003).

\section{Conclusion}

The present investigation showed that Niacin and ivy separate, diminished the provocative arbiters, and enhanced cell reinforcement resistance. Besides, Goblet cells hyperplasia and NF were likewise controlled. These results suggest that two drugs exhibit inhibitory activities not only for allergen-induced inflammatory mediators but also for oxidant system, probably due to the down regulation of allergen sensitization. The present results suggest that two drugs might offer a new therapeutic approach to allergic airway diseases probably Niacin is more potent than Hedera helix extract.

The authors declare that there is no conflict of interest

\section{References:}

"Asthma Fact sheet $N^{\circ} 307 "$. WHO. November (2013). Retrieved 3 March 2016.

Albuquerque RV, Hayden CM, Palmer LJ, et al. (1998). Association of 
polymorphisms within the tumour necrosis factor (TNF) genes and childhood asthma. Clin Exp Allergy; 28:578-84.

Aldridge RE, Chan T, van Dalen CJ, et al. (2002). Eosinophil per oxidase produces hypobromous acid in the airways of stable asthmatics. Free Radic Biol Med; 33:847-56.

Antonicelli F, Parmentier M, Drost EM, et al. (2002). Nacystelyn inhibits oxidant-mediated interleukin-8 expression and $\mathrm{NF}-\kappa \mathrm{B}$ nuclear binding in alveolar epithelial cells. Free Radical Biology and Medicine. 32(6):492-502.

Aulak KS, Miyagi M, Yan L, West KA, Massillon D, Crabb JW, and Stuehr DJ (2001). Proteomic method identifies proteins nitrated in vivo during inflammatory challenge. Proc Natl Acad Sci USA 98: 12056-12061.

Aylward M (1979). Hexopal in Raynaud's disease. J Int Med Res;7: 484-491.

Bancroft JD, Stevens A (1996). Theory and Practice of histological techniques, $4^{\text {th }} \quad \mathrm{Ed}^{\mathrm{n}}$. Churchill Livingstone, London.

Barnes PJ, Chung KF and Page CP (1999). Inflammatory mediators of asthma: An update. Pharmacol Rev; 50(4):515-96.

Barnes PJ. (2000). Chronic obstructive pulmonary disease. N Engl J Med. 343:269-80.

Blesa S, Cortijo J, Mata M, Serrano A, Closa D, Santangelo F, et al. (2003). Oral N-acetylcysteine attenuates the rat pulmonary inflammatory response to antigen. Eur Respir J; 21:394-400.

Bloemen, K, S Verstraelen, R Van Den Heuvel, H Witters, I Nelissen, G Schoeters (2007). The allergic cascade: Review of the most important molecules in the asthmatic lung. Immunology Letters., 113(1): 6 -18.

Bolbot Y, Prokhorov E, Mokia S, Yurtseva A (2004). Comparing the efficacy and safety of high-concentrate (5-
7.5: 1) ivy leaves extract and acetylcysteine for treatment of children with acute bronchitis. Drugs of Ukraine; 11: 1-4.

Bradding P, ST Holgate (1999). Immuno pathology and human mast cell cytokines. Crit Rev Oncol Hematol., 31(2): 119-133.

Brown BG and Zhao XQ (2008). Nicotinic acid alone and in combinations for reduction of cardiovascular risk. Am J Cardiol. 101(8A):5862.

Calikoglu M, Unlu A, Tamer L, Ercan B, Bugdayci R, Atik U (2002). The levels of serum vitamin $\mathrm{C}$, malonyldialdehyde and erythrocyte reduced glutation in chronic obstructive pulmonary disease and in healthy smokers. Clin Chem Lab Med. 40:1028-31.

Cho KH, Kim HJ, Rodriguez-Iturbe B and Vaziri ND (2009). Niacin ameliorates oxidative stress, inflammation, proteinuria, and hypertension in rats with chronic renal failure. Am J Physiol Renal Physiol 297: F106-F113.

Chung-Man HJ, Zheng S, Comhair SA, Farver C, Erzurum SC. (2001). Differential expression of manganese superoxide dismutase and catalase in lung cancer. Cancer Res. 61: 8578-85.

Cluzel M, Damon M, Chanez P, Bousquet J, Crastes DP, Michel FB and Godard P (1987). Enhanced alveolar cell luminal-dependent chemiluminescence in asthma. $\mathbf{J}$ Allergy Clin Immunol 80, 195201.; Hulsmann AR, Raatgeep HR, den Hollander JC, Stijnen T, Saxena PR and Kerrebijn KF et al. (1994). Oxidative epithelial damage produces hyper responsiveness of human peripheral airways. Am J Respir Crit Care Med 149, 519525.

Coles H (1980). veterinary clinical pathology 3rd ed., W. B. saunder's Co. Philadelphia. 
Comhair SA, Bhathena PR, Dweik RA, Kavuru M and Erzurum SC (2000). Rapid loss of superoxide dismutase activity during antigen-induced asthmatic response. Lancet 355, 624.; Comhair, S. A., Ricci, K. S., Arroliga, M., Lara, A. R., Dweik, R. A., Song, W. et al. (2005a). Correlation of systemic superoxide dismutase deficiency to airflow obstruction in asthma. Am J Respir Crit Care Med 172, 306-313.; Comhair SA, $\mathrm{Xu}$ W, Ghosh S, Thunnissen FB, Almasan A, Calhoun WJ et al. (2005b). Superoxide dismutase inactivation in patho physiology of asthmatic airway remodeling and reactivity. Am J Pathol 166, 663-674.

Cookson B (1999). The alliance of genes and environment in asthma and allergy. Nature; 402:B5-11.

Cwientzek U, Ottillinger B and Arenberger P (2011). Acute bronchitis therapy with ivy leaves extracts in a twoarm study. A double-blind, randomized study vs. another ivy leaves extract. Phytomedicine; 18: 1105- 1109.

D'Amato et al. (2013). wildirismedicaleducation.com

Davies RJ, Wang J, Jiahua W, Abdelaziz M, Calderon MA, Khair O, Devalia JL and Rusznak C. (1997). New insights into the understanding of asthma. Chest; 111:2-10.

Fazio S, Pouso J, Dolinsky D, Fernandez A, Hernandez M, Clavier G. et al. (2009). Tolerance, safety and efficacy of Hedera helix extract in inflammatory bronchial diseases under clinical practice conditions: a prospective, open, multicentre postmarketing study in 9657 patients. Phytomedicine. 16(1):1724.

Gaillard Y, Blaise P, Darre A, Barbier T and Pepin G (2003). An unusual case of death: suffocation caused by leaves of common ivy (Hedera helix). Detection of hederacoside $\mathrm{C}$, alpha-hederin, and hederagenin by
LC-EI/MS-MS. J Anal Toxicol; 27(4):257-262. 12820750.

Gambhir D, Ananth S, VeerananKarmegam R, Elangovan S, Hester $\mathrm{S}$, et al. (2012). GPR109A as an anti-inflammatory receptor in retinal pigment epithelial cells and its relevance to diabetic retinopathy. Invest Ophthalmol Vis Sci 53: 2208-17.

Ganji SH, Qin S, Zhang L, Kamanna VS, Kashyap ML (2009). Niacin inhibits vascular oxidative stress, redox-sensitive genes, and monocyte adhesion to human aortic endothelial cells. Atherosclerosis. 202 (1):6875.

Gillissen A, Jaworska M, Scharling B, et al. (1997a). Beta-2-agonists have antioxidant function in vitro. 1 . Inhibition of superoxide anion, hydrogen peroxide, hypochlorous acid and hydroxyl radical. Respiration, 64:16-22.

Gillissen A, Wickenburg D, van Zwoll D, et al. (1997b). Beta-2-agonists have antioxidant function in vitro. 2. The effect of beta-2-agonists on oxidantmediated cytotoxicity and on superoxide anion generated by human polymorphonuclear leukocytes. Respiration, 64:23-8.

Gilmore TD (October 2006). "Introduction to NF-kappaB: players, pathways, perspectives". Oncogene. 25 (51): 6680-4.

Gosset P, Tsicopoulos A, Wallaert B, et al. (1992). Tumor necrosis factor- $\alpha$ and interleukin-6 production by human mononuclear phagocytes from allergic asthmatics after $\operatorname{IgE}$ dependent stimulation. Am Rev Respir Dis; 146:768-74.

Hedayati, M., yazdanparast, R., \& Azizi, F (2001). Determination of human tumor necrosis factor $\alpha$ by a highly sensitive enzyme immunoassay. Biochemical and biophysical research communications, 289, 295-298. 
Henderson WR Jr, Chi EY, Teo JL, Nguyen C, Kahn M (2002). A small molecule inhibitor of redoxregulated NF-kappa B and activator protein-1 transcription blocks allergic airway inflammation in a mouse asthma model. J Immunol; 169: 5294-9

Hirata N, Konrogi $\mathrm{H}$, Iwagoe $\mathrm{H}$, et al. (1998). Allergen exposure induces the expression of endothelial adhesion molecules in passively sensitized human bronchus; time course and the role of cytokines. Am J Repir Cell MolBiol; 18:1220.

Holt PG, Macaubas C, Stumbles PA, et al. (1999). The role of allergy in the development of asthma. Nature; 402:B12-17.

Horne R (2006). Compliance, adherence, and concordance: implications for asthma treatment. Chest 130:65S$72 \mathrm{~S}$.

Jollow D J, Michell JR and Zampaglionic and Gillete JR (1974). Bromobenzene induced Liver necrosis: Protective role of glutathione and evidence for 3,4 bromobenzene oxide as hepatotoxic metabolite. Pharmacology, 11: 151-169.

Kharitonov SA, Barnes PJ (2001). Exhaled markers of pulmonary disease. Am J Respir Crit Care Med; 163: 1693722.

Kuvin JT, Dave DM, Sliney KA, et al. (2006). Effects of extended-release niacin on lipoprotein particle size, distribution, and inflammatory markers in patients with coronary artery disease. American Journal of Cardiology. 98(6):743-745.

Kwon WY, Suh GJ, Kim KS and Kwak YH (2011). Niacin attenuates lung inflammation and improves survival during sepsis by down regulating the nuclear factorkappaB pathway. Crit. Care Med. 39, 328-334.

Lapenna D, De Gioia S, Mezzetti A, et al. (1995). Aminophylline: could it act as an antioxidant in vivo? Eur $\mathbf{J}$ Clin Invest, 25:464-70.

Li T, Molteni A, Latkovich P, Castellani W, Baybutt RC. (2003).Vitamin A depletion induced by cigarette smoke is associated with the development of emphysema in rats. J Nutr;133: 2629-34.

Lowry MH, McAllister BP, Jean J-C, et al. (2008). Lung lining fluid glutathione attenuates IL-13induced asthma. American Journal of Respiratory Cell and Molecular Biology. 38(5):509-516.

Lowry OH, Rosebrough NJ, Farr AL and Randall RJ (1951). Protein measurement with the Folin phenol reagent. J. of Biological Chemistry, 193: 265-275.

Mainardi T, S Kapoor, L Bielory (2009). Complementary and alternative medicine: Herbs, phytochemicals and vitamins and their immunologic effects. J Allergy Clin Immunol., 123: 283-294.

Martinez FD (2007). "Genes, environments, development and asthma: a reappraisal". European Respiratory Journal 29 (1): 17984.doi:10.1183/09031936.0008790 6. PMID 17197483.

Message SD, Johnston SL (2002). Viruses in asthma. Br Med Bull; 61:29-43.

Nadeem A, Raj HG and Chhabra SK (2005). Increased oxidative stress in acute exacerbations of asthma. $\mathbf{J}$ Asthma 42, 45- 50.

NHLBI Guideline (2007). pp. 11-12.

Ozdemir C, Schneider LA, Hinrichs R, Staib G, Weber L, Weiss JM, et al. (2003). [Allergic contact dermatitis to common ivy (Hedera helix L.)]. Hautarzt. 54(10):966-9.

Radwan, E H, A Abdel Mawgood, AZ Ghonim, REl nagar (2018).The possibility of using the fresh water bivalve, Spathopsis rubins, in the Nile River, El Mahmoudia water stream as bioindicator for pollution. International journal of Limnology,(1), (1),1-23. 
Radwan EH, AA Hassan, GH Fahmy, SS ElShewemi, SH Abdel Salam, (2018). Impact of environmental pollutants and parasites on the ultrastructure of the Nile bolti, Oreochromis auruis. Journal of bioscience and applied research, (4)(1)58-83.

Radwan EH, MM Elghazaly, H Kh Hussein, KKAbdel Aziz, AI Barakat(2020). The possible effects of sodium nitite and sodium benzoate as food additives on the liver in male rats.Journal of advances in biology, (13), 14-30.

Ribeiro-Filho J, Calheiros AS, Vieira-deAbreu A, de Carvalho KI, da Silva Mendes D, Melo CB, et al. (2013). Curine inhibits eosinophil activation and airway hyperresponsiveness in a mouse model of allergic asthma. Toxicol Appl Pharmacol; 273:19-26

Richardson G, Benjamin N (2002). Potential therapeutic uses for Snitrosothiols. Clin Sci (Lond) ;102:99-105.

Sahin U, Unlu M, Ozguner F, Sutcu R, Akkaya A, Delibas N (2001). Lipid peroxidation and glutationa peroxidase activity in chronic obstructive pulmonary disease exacerbation: prognostic value of malondialdehyde. J Basic Clin Physiol Pharmacol. 12:59-68.

Sedlak J and Lindsay RH (1968). Estimation of total, protein bound and non-protein bound sulfhydryl groups in tissues with Ellman's reagent. Analytical Biochemistry, 25: 192-205.

Seltzer J, Bigby BG, Stulbarg M, Holtzman MJ, Nadel JA, Ueki IF et al. (1986). O3-induced change in bronchial reactivity to methacholine and airway inflammation in humans. J Appl Physiol 60, 13211326.; Hiltermann TJ, Peters EA, Alberts B, Kwikkers K, Borggreven PA, Hiemstra PS et al. (1998). Ozone-induced airway hyperresponsiveness in patients with asthma: role of neutrophilderived serine proteinases. Free Radic Biol Med 24, 952- 958.

Si Y, et al. (2014). Niacin Inhibits Vascular Inflammation via Down regulating Nuclear Transcription Factor $-\kappa \mathrm{B} \quad$ Signaling Pathway. Mediators Inflamm. 2014, 263786.

Sieben A, Prenner L, Sorkalla T,Wolf A, Jakobs D, Runkel F, Häberlein $\mathrm{H}$ (2009). $\alpha$-Hederin, but not hederacoside $\mathrm{C}$ and hederagenin from Hedera helix, affects the binding behaviour, dynamics, and regulation of $\beta 2$-adrenergic receptors. Biochemistry; 48: $3477-$ 3482.

Stauss-Grabo M, Atiye S (2009). Efeu eine traditionelle Heilpflanze in der modernen Phytotherapie. Z Phytother; 30: 289-291.

Trute A, Gross J, Mutschler E, Nahrstedt A (1997). In vitro antispasmodic compounds of the dry extract obtained from Hedera helix. Planta Med, 63(2):125-9.

Veit M. (2014). Gleiche Quelle, gleiche Wirkung? Dtsch Apoth Ztg; 33: 3518-3523.

Villani P, Orsiere T, Sari-Minodier I, Bouvenot G and Botta A (2001). [In vitro study of the antimutagenic activity of alphahederin]. Ann Biol Clin (Paris) 59(3):285-289. 11397676.

Wardlaw AJ, Dunnette S, Gleich GJ, Collins JV and Kay AB (1988). Eosinophils and mast cells in bronchoalveolar lavage in subjects with mild asthma. Relationship to bronchial hyperreactivity. Am Rev Respir Dis 137, 62- 69.

Wood LG, Fitzgerald DA, Gibson PG, Cooper DM, Garg ML. (2000). Lipid peroxidation as determined by plasma isoprostanes is related to disease severity in mild asthma. Lipids; 35:967-74.

$\mathrm{Wu}$ BJ, Chen K, Barter PJ, Rye KA (2012). Niacin Inhibits Vascular 
Inflammation via the Induction of Heme Oxygenase-

1. Circulation. 125(1):150-8.

Wu W, Samoszuk MK, Comhair SA, Thomassen MJ, Farver CF, Dweik RA et al. (2000). Eosinophils generate brominating oxidants in allergen-induced asthma. J Clin Invest 105, 1455- 1463.

Yasui K, Agematsu K, Shinozaki K, et al. (2000). Effects of theophylline on human eosinophil functions: comparative study with neutrophil functions. J Leukoc Biol; 68:194200.

Yates DH, Barnes PJ, Thomas PS (1993). Tumor necrosis factor alters human bronchial reactivity and induces inflammatory cell influx. Am Rev Respir Dis 1993; 147:A1011.

Zeil S, Schwanebeck U and Vogelberg C (2014).Tolerance and effect of an add-on treatment with a cough medicine containing ivy leaves dry extract on lung function in children with bronchial asthma. Phytomedicine; 21: 1216-1220.

Zheng L, Nukuna B, Brennan ML, Sun M, Goormastic M, Settle M, Schmitt $\mathrm{D}, \mathrm{Fu} \mathrm{X}$, Thomson L, Fox PL, Ischiropoulos H, Smith JD, Kinter M, and Hazen SL (2004). Apolipoprotein AI is a selective target for myeloperoxidasecatalyzed oxidation and functional impairment in subjects with cardiovascular disease. J Clin Invest 114: 529-541. 